\title{
Modeling the Past: The Paleoethnological Evidence
}

\author{
Paolo Biagi* \\ Department of Asian and North African Studies, Ca' Foscari University - Venice, Venezia, Italy
}

\begin{abstract}
This chapter considers the earliest Paleolithic, Oldowan (Mode 1), and Acheulean (Mode 2) cultures of the Old Continent and the traces left by the earliest hominids since their departure from Africa. According to the most recent archaeological data, they seem to have followed two main dispersal routes across the Arabian Peninsula toward the Levant, to the north, and the Indian subcontinent, to the east. According to recent discoveries at Dmanisi in the Caucasus, the first Paleolithic settlement of Europe is dated to some 1.75 Myr ago, which indicates that the first "out of Africa" took place at least slightly before this date. The data available for Western Europe show that the first Paleolithic sites can be attributed to the period slightly before 1.0 Myr ago. The first well-defined "structural remains" so far discovered in Europe are those of Isernia La Pineta in Southern Italy, where a semicircular artificial platform made of stone boulders and animal bones has been excavated. The first hand-thrown hunting weapons come from the site of Schöningen in north Germany, where the first occurrence of wooden spears, more than $2 \mathrm{~m}$ long, has been recorded from a site attributed to some $0.37 \mathrm{Myr}$ ago. Slightly later began the regular control of fire. Although most of the archaeological finds of these ages consist of chipped stone artifacts, indications of art seem to be already present in the Acheulean of Africa and the Indian subcontinent.
\end{abstract}

\section{Introduction}

The aim of this chapter is to review the current evidence for the paleoethnology of the early hominids who inhabited the Old World from the time of their appearance up to the end of the Middle Pleistocene. Although the data presently available are not abundant, there is no doubt that they are of key importance for the understanding of early hominid behavior and lifestyles. The evidence is limited in most cases to stone tools and their contexts (Clark 1968, p. 277), almost exclusively due to natural and environmental factors both physical and biological (Stiles 1998, p. 134; McNabb 2009).

Given that the term paleoethnology rarely occurs in the Anglo-Saxon literature, while it is, or better was, more common in several European countries, it may be useful to review the meaning of this term and how it originated. It derives from the Greek palaiòs èthnos lògos (study of ancient populations) and was first used in France around the middle of the nineteenth century, and immediately afterward in Italy when prehistoric studies began to flourish, mainly in the Po Valley region of Emilia. The term paleoethnology (Pigorini 1866; Regazzoni 1885) was formally adopted

\footnotetext{
*Email: pavelius@unive.it

*Email: paolo.biagi@unive.it
} 
during a congress exclusively devoted to the new science ("scienza nuova") held in La Spezia on September 20, 1865, by the Italian Society of Natural Sciences (Tarantini 2012, p. 30). At this meeting, the French engineer Gabriel de Mortillet proposed the foundation of an International Paleoethnological Congress that was enthusiastically accepted by all delegates. A few years later, in 1875, Luigi Pigorini (Guidi 1987), Gaetano Chierici (Magnani 2007), and Pellegrino von Strobel (von Strobel 1998) founded a new journal in Parma, "Bullettino di Paletnologia Italiana," the first to exclusively deal with prehistoric archaeology".

In those years, the term paleoethnology was preferred to that of prehistoric archaeology because it was more strictly connected with the ethnographic discoveries under way in the Americas, Africa, and Asia (Figuier 1870, p. 415; Lubbock 1870) and favored analogy studies (Hodder 1982, p. 12) between the prehistoric finds recovered from excavations in European prehistoric sites and those still in use among the native communities of the above continents (Desittere 1988). In this respect, it is important to remark that even Boucher de Perthes (1864), the famous discoverer of Abbeville and the first Early Paleolithic hand axes in continental Europe (Prestwich 1860; LamdinWhymark 2009, p. 49), had a collection of flint tools from not only Europe but also Asia and Africa (Gowlett 2009, p. 18). This is the reason why paleoethnology courses are still delivered in the Italian university, due to the long tradition that goes back to the earliest prehistoric studies of the mid-nineteenth century.

Reverting to the early stone tool assemblages of the first hominids, they are often associated with alluvial sedimentary processes (Isaac 1967) related to the geographic and geomorphologic location and distribution of the (sometimes ephemeral) sites (Brown 1997, p. 150) that in many cases are limited to the stone tools themselves and possibly to organogenic tools and the faunal remains derived from hunting and scavenging activities (Conard 2007). Nevertheless, the excavations carried out during the last 50 years, and the study of the settlement structures and tool assemblages of the Early Paleolithic sites of the Old World, "have shown that it is quite possible to find sealed occupation sites that have suffered little or no natural disturbance before or after burial" (Clark 1968, p. 276).

As far as the remains of material culture and their chronotypological characteristics are concerned, this chapter deals almost exclusively with Mode 1 (Oldowan) and Mode 2 (Acheulean) complexes (Clark 1994; Toth and Schick 2007). Tools belonging to these two "modes" have been collected from a great number of sites, which are distributed between East Africa and the Indian subcontinent in the southeast and Europe in the northwest (Movius 1948, p. 409; Otte 2000, p. 111).

\section{Out of Africa}

Much has been published dealing with the spread of the first hominids and the radiometric dating(s) of the "out of Africa" dispersal(s) (Chauhan 2005; Petraglia 2007; Rightmire 2007). Nevertheless, many questions are still unresolved, since "the triggers for the movement of humans out of Africa are not well known" (Bar-Yosef and Belfer-Cohen 2000, p. 81). Stone tool technotypological variability, between Africa and Asia, for instance, would suggest a series of cultural complexities (Braun et al. 2010). The chronology is also very variable and badly known, in India for instance (see Chauhan 2010 contra Gaillard et al. 2010). This state of affairs results from the absence or scarcity of reliable data from some of the key territories that hominids must undoubtedly have crossed to reach Eurasia (see, for instance, Petraglia 2003, Fig. 12).

This is the case for Arabia, from which little information is currently available, especially from the southern portions of the peninsula, more precisely Yemen (Dhofar) and Oman, which were 


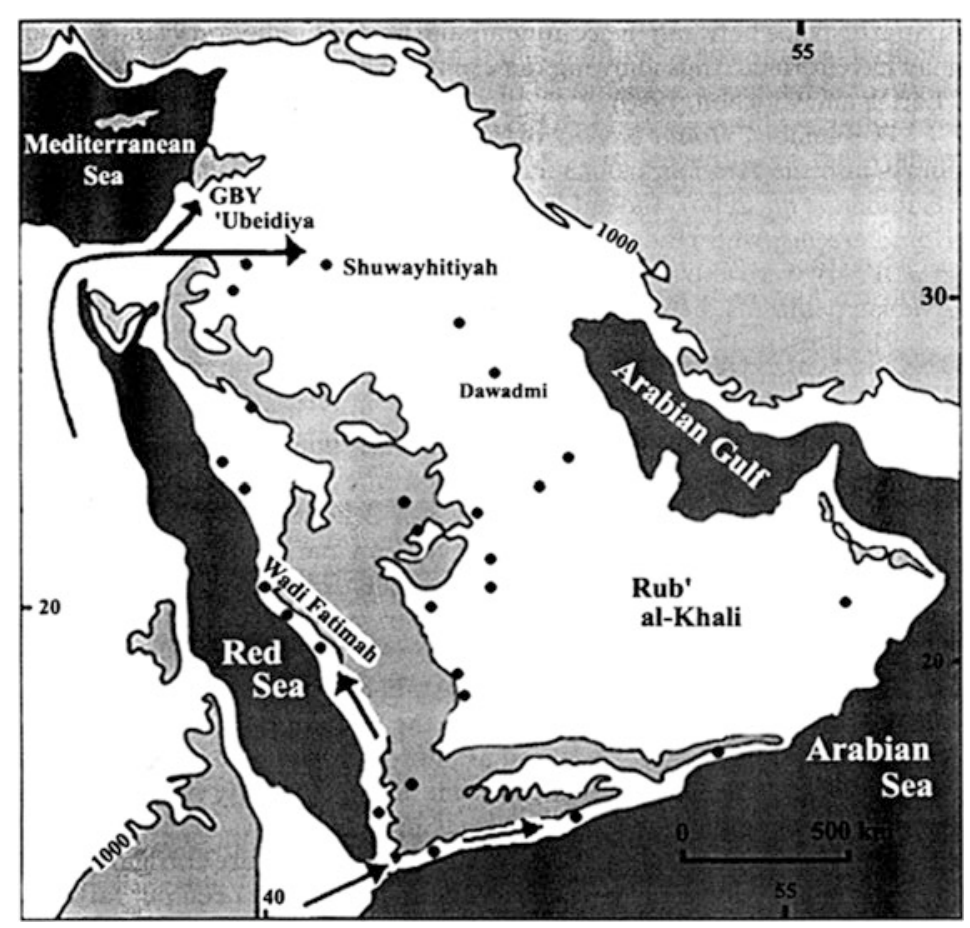

Fig. 1 The Arabian Peninsula with the indication of the most important Early Paleolithic sites (dots) and the potential main routes followed by hominids during their "out of Africa" dispersal(s) (arrows) (After Petraglia 2003, Fig. 12)

most probably reached by the Afar Depression across the dried Red Sea strait (Cachel and Harris 2007, p. 120). Effectively, the Early Paleolithic sites discovered in these countries come from a few, restricted areas where intensive surveys and excavations have been carried out in the last two decades (Whalen and Pease 1991; Cremaschi and Negrino 2002; Whalen et al. 2002; Whalen and Fritz 2004; Amirkhanov 2006). Even though many of them are represented by surface finds, the Soviet-Yemeni Archeological Mission excavated thick sequences in some caves of southeast Yemen, close to the Dhofar border. This led to the discovery of stratified complexes, which Amirkhanov (1994, p. 218) attributed to the pre-Acheulean (Oldowan: Mode 1) and Acheulean (Mode 2) periods. In this context, the only tool bearing evident traces of use, from the lowermost layers of Al-Guza Cave in Yemen (Amirkhanov 2006, p. 91), is of unique importance. This is the only pre-Acheulean worn chopper so far known from the entire south Arabian Peninsula.

Although the Early Paleolithic sites so far discovered in this region are few, south Arabia is claimed to represent one of the key routes followed by the first hominids once they started to move out of Africa, initially moving along the coast of the peninsula, to reach its interior slightly later (Rose and Petraglia 2009, p. 6), moving to the central territories of the Indian subcontinent, undoubtedly earlier than 1.0 Myr ago (Bar-Yosef and Belfer-Cohen 2000, p. 82). A second route is said to have been followed "across the Sinai into western Asia ... although this has not been adequately detailed to date" (Bar-Yosef 1994, p. 237; Petraglia 2003, pp. 168-169), where the oldest site known to date is located at Ubeidiya (Stekelis et al. 1969; Bar-Yosef 1995, p. 250) (Fig. 1).

Important radiometric dates for the first human dispersal are available from Dmanisi (Fig. 2) in the Georgian Caucasus (Gabunia et al. 1999; Nioradze and Nioradze 2011). The excavations carried out at this site over a surface of some 300 sqm led to the discovery of a unique settlement with skeletal remains of early hominids, identified as Homo ergaster (Lordkipanidze and Vekua 2006), among which are five skulls, over 10,000 chipped stones obtained from different raw 


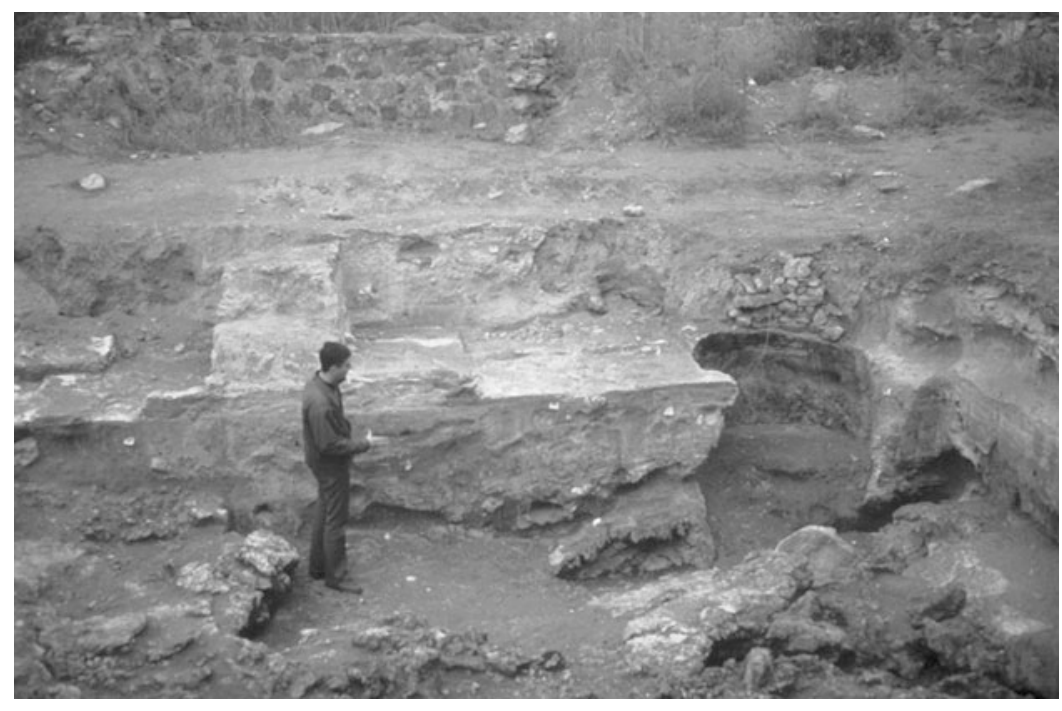

Fig. 2 Dmanisi (Georgia): A view of the hominid archaeological site with the Medieval pit (on the right) from which the first prehistoric bones were discovered (Photograph by P. Biagi)

materials (for instance, mostly available close to the site as river pebbles), mainly represented by choppers and flakes, and over 7,000 animal bones, belonging to a faunal assemblage of "Villafranchian type." They undoubtedly show that this dispersal took place not later than 1.8 Myr ago (Gabunia 2000, p. 43; Vekua et al. 2011). Nevertheless, "le mouvement oriental paraît à la fois beaucoup plus complexe et, surtout, beaucoup plus ancien qu'en Europe" (Otte 2000, p. 108). Fortunately, the number of discoveries of Lower Pleistocene sites from this continent is systematically increasing (de Lumley 1976; Agustí et al. 2000; Mussi 2001, p. 20). Although the absolute age of some of these sites is problematic (Santonja and Villa 1990, p. 54), many are undoubtedly much older than supposed only a few years ago (Roebroeks and van Kolfschoten 1994, p. 500). Although the number of radiometric dates currently available from southern Europe is very limited, nevertheless they show that at least some north Mediterranean regions were undoubtedly settled by hominids as early as $1.3 \mathrm{Myr}$ ago (see, for instance, de Lumley et al. 1988; Peretto et al. 1999; Toro-Moyano et al. 2003) as suggested by recent discoveries made at Pirro Nord, in southeastern Italy (Arzarello et al. 2007, 2012).

\section{Chipped Stone Assemblages}

\section{Bifaces and Other Tools}

As pointed out by Gowlett (2005, p. 51), "East Africa is the key territory for examining the Oldowan and early Acheulean," in which the first "bifacial tools were created about 1.5 million years ago" (Porr 2005, p. 68) by Homo ergaster, as a consequence of a complex series of behavioral, economic, and social factors whose complexity has been pointed out by Porr (2005, p. 77). Until recently, however, they have been considered almost exclusively in the context of "artefacts as a functional form that varies sometimes according to raw material considerations and is manufactured with a recurrent technology within broader parameters" (Ashton and McNabb 1993, p. 190). But the fact that the manufacture of such tools continued for some 1.25 Myr indicates their importance, most probably not only as cutting and/or scavenging weapons (DomínguezRodrigo 2002) but also as social indicators independent of their functional meaning(s). According 


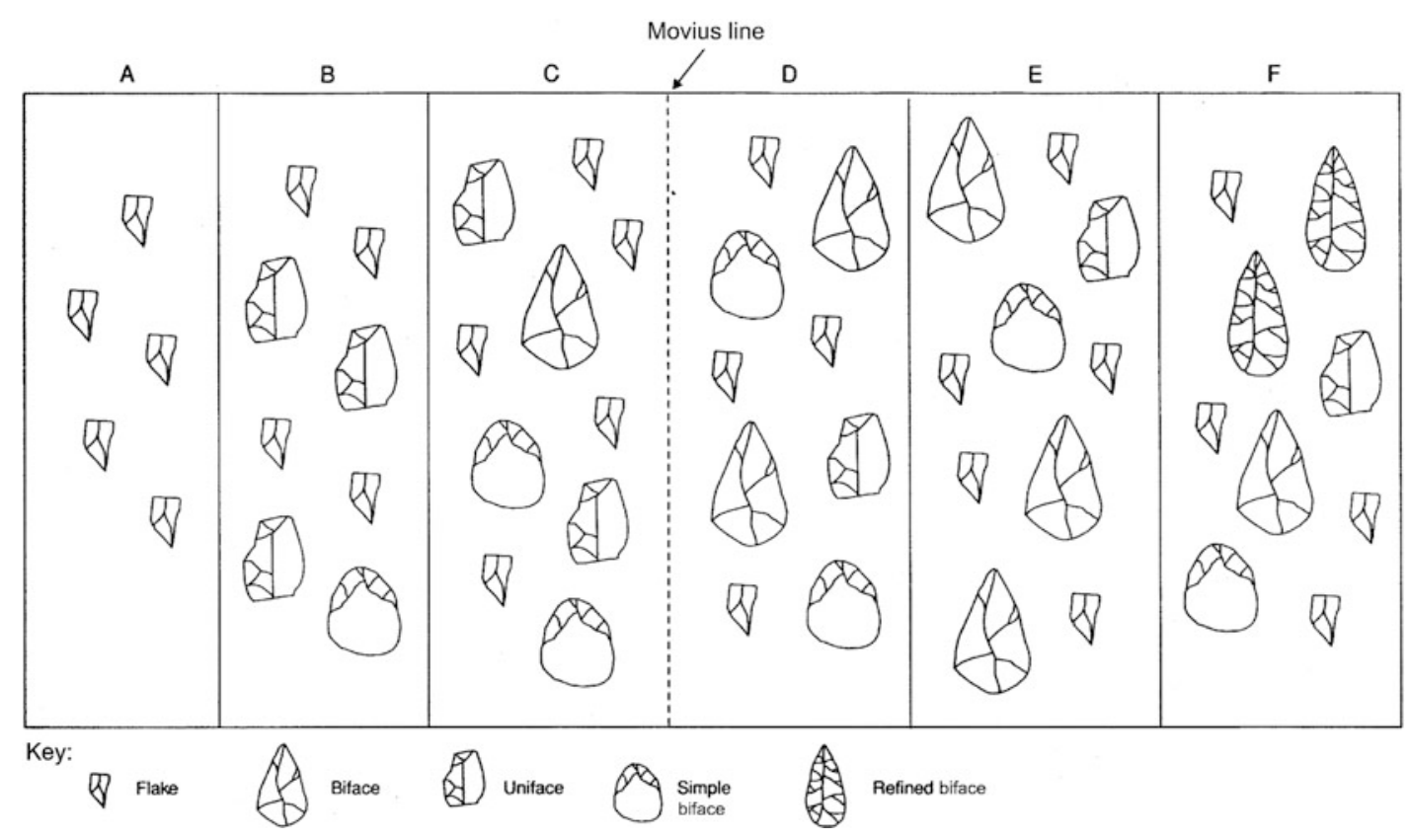

Fig. 3 Variation among lower Paleolithic biface assemblages of Eastern Asia and South Asia. The dashed line represents the Movius Line, the traditional demarcation between Mode 1 (Oldowan) and Mode 2 (Acheulean) industries (After Petraglia 1998, Fig. 11.8)

to Draper (1985, p. 7), “we could imagine a situation where an Early Paleolithic hominid might have fabricated a portable cutting tool for scavenging remnant meat from carnivore kills" that "was produced because a Middle Pleistocene knapper ... was disposed to work stone in a way that produced an object we call a handaxe" (Hopkinson and White 2005, p. 21). The high variability (Sinclair and McNabb 2005, p. 185), the typological and dimensional characteristics (Isaac 1977), their eventual hafting (Ling 2011), and the "wide temporal and geographic distribution" (Wynn 1995, p. 11) of these tools have been noted by many authors, but from different perspectives and with different aims (Bordes 1968, p. 23; Camps 1979; Petraglia 1998, p. 371; McNabb et al. 2004; Hopkinson and White 2005) (Figs. 3 and 4). In Asia, their distribution covers a well-defined region, delimited in the east and the north by the so-called Movius Line (Movius 1944, p. 103), more of a "veil" than a real line according to Otte (2010, p. 274). This "line" is still nowadays often employed to mark the limit between hand axe and other technologies with no evidence of bifacial tools, like the Soanian of northern Pakistan (De Terra and Paterson 1939; Paterson and Drummond 1962), though bifacial tools are recorded from its more recent period of development (Graziosi 1964, p. 12), or the Anyathian of Burma (De Terra and Movius 1943) to make two well-known examples often referred to very different chronological periods of the Paleolithic. In this respect, the discovery of undated bifacial forms in Australia is intriguing and might possibly help clarify some aspects of their manufacture, meaning, and function (Brumm and Rainey 2011).

Although the complexity involved in the production of the lithic artifacts has been openly questioned (Hassan 1988, p. 281), and analysis of manufacturing techniques and debitage dispersal (Andrefsky 2007) across the earliest Paleolithic sites (Gowlett 2005; Petraglia et al. 2005) is still rarely applied by the field archaeologists, a few interesting exceptions should be mentioned. Among these is the MNK chert factory site in the Olduvai Gorge (Tanzania), which is dated to some 1.6 Myr ago. Here chipped stone artifacts, obtained from both local and imported raw materials, show a complex sequence of activities carried out by "early man working a raw material chosen for its technological properties brought to a central locality from diverse sources" (Stiles 
a
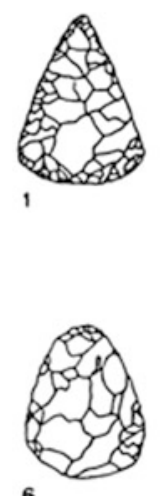

6
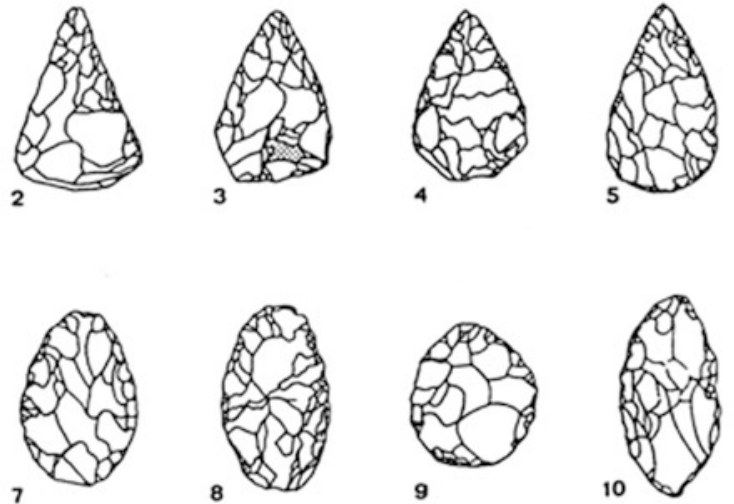

b
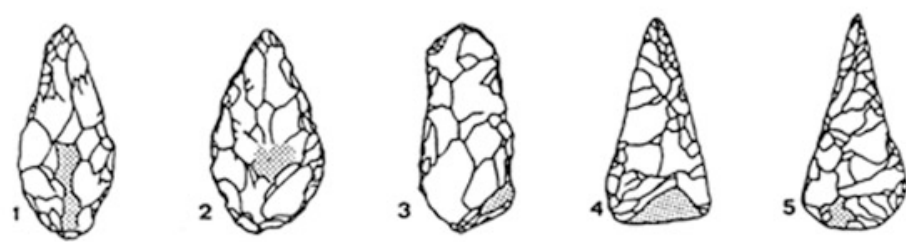

C
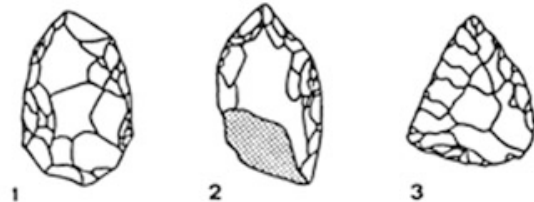

3
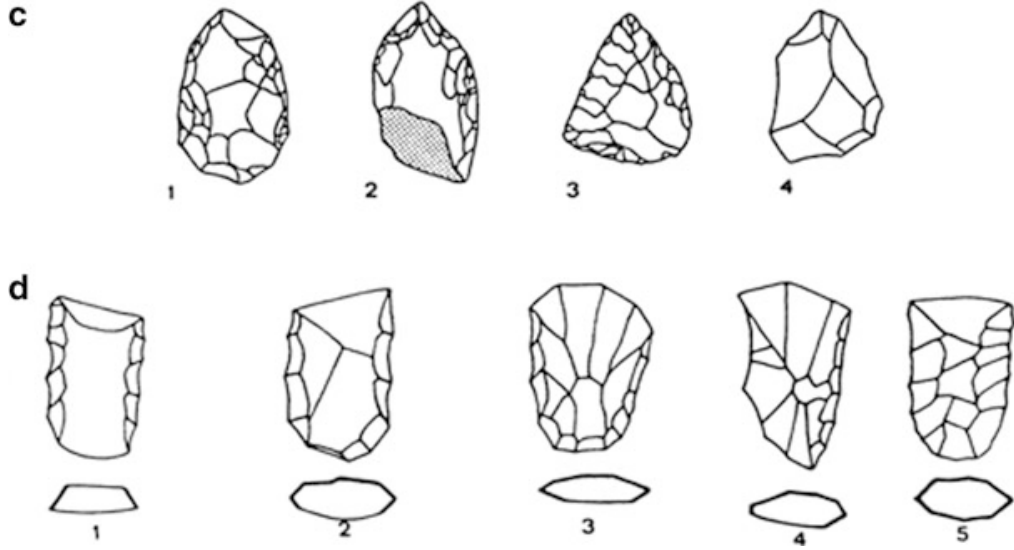

Fig. 4 Different categories of hand axes according to the typological classification proposed by Camps (1979): different types of a flat bifacials, b thick bifacials, c diverse bifacials, and $\mathbf{d}$ hachereaux (After Broglio 1998, Fig. 22)

et al. 1974). FxJi50, in north Kenya, is a site 1.5 Myr old that "consists of a patch of stone artefacts interspersed with broken-up fragments of bone" (Bunn et al. 1980, p. 111), whose precise function is still difficult to define. The chipped stone assemblage, which is composed of flaked cobbles and flakes partly obtained on the spot, "has proved to consist of several dense clusters of material that interconnect with each other" (Bunn et al. 1980, p. 114). This is one of the earliest Paleolithic sites from which "the close association (of bones) with artefacts and the presence of butchering marks suggest that the toolmakers were the first accumulating agency" (Bunn et al. 1980, p. 125). This picture is rather unusual, if we consider that "for most of the sites excavated and reported we do not have certain indications of any specific activities that characterize them, and in very few instances has localization of subsidiary tool kits within a floor even been claimed" (Isaac 1972, p. 185) and that the interpretation of the variability of the spatial distribution pattern of the tools (Whallon 1973, p. 117) within a site surface is often difficult (Keeley 1991, p. 258). Experimental studies have also been made especially regarding hand-axe production employing different techniques and raw materials and using both hard and soft hammerstones (Madsen and Goren-Inbar 2004). 


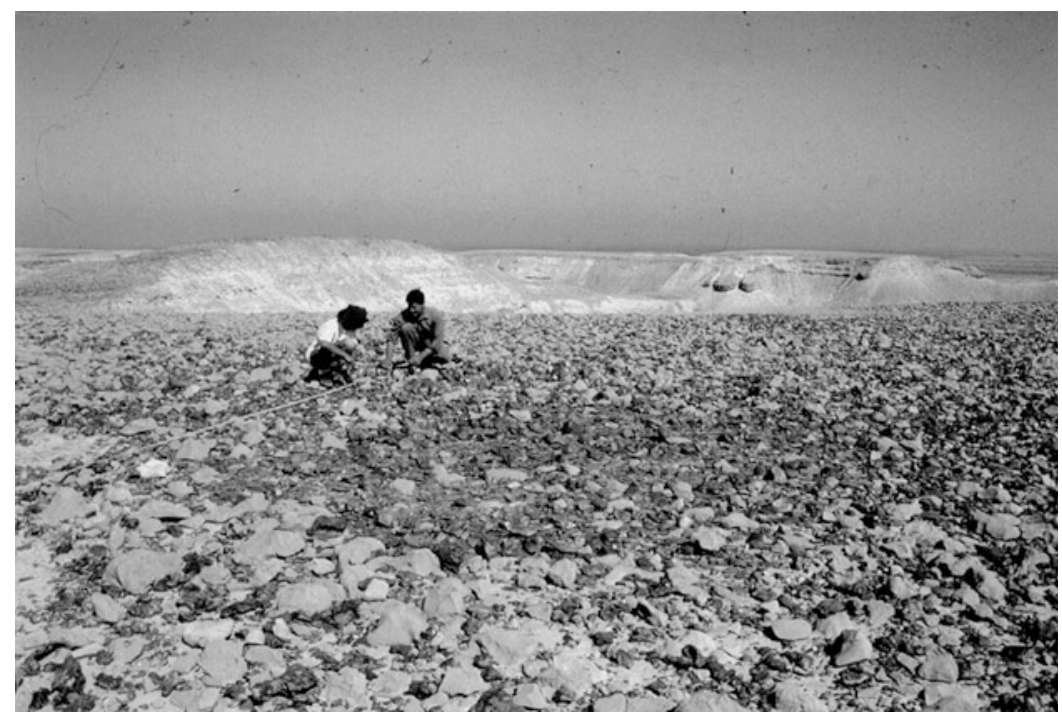

Fig. 5 Ziarāt Pir Shabān on the Rohri Hills (Sindh, Pakistan): The Acheulean hand-axe factory ZPS1 before excavation (Photograph by P. Biagi)

\section{Raw Material, Workshops, and Quarries}

When detailed recording methods have been applied, as for instance in the case of some localities excavated in the Indian subcontinent, they have revealed that characteristic tools, among them hand axes, cores, hammerstones, and different dimensional classes of debitage flakes, systematically cluster in well-defined spots (see Pappu 2001, pp. 25-54; Paddayya et al. 2002, p. 646). This fact is useful in helping us understand the development of the manufacturing areas within the site and the steps followed by the toolmakers during the production process (Hansen and Madsen 1983, p. 51), especially when refitting methods are applied to the entire complex (Bergman et al. 1990, p. 280). This is the case for the some Acheulean sites where different varieties of raw materials for tool production were available, including siliceous limestone (Isampur in India: Petraglia et al. 2005) and good-quality chert from local outcrops (Rohri Hills in Sindh [Pakistan]: Biagi et al. 1996).

The evidence available from the latter shows that the waste products of large hand-axemanufacturing workshops were scattered along the edges of circular sandy areas representing zones that were comprehensively cleared of limestone and chert boulders in Paleolithic times, before the manufacturing activities took place. For instance, the excavations carried out at Ziarāt Pir Shabān 1 (Fig. 5), one of the many Acheulean workshops discovered on the Rohri Hills that were exclusively devoted to the production of hand axes (Biagi et al. 1996) (Fig. 6), have demonstrated that the perfect, finished bifaces were exclusively transported elsewhere, most probably to camps located in the adjacent Great Indian Desert that are at present buried beneath meters of sand inside thick, stabilized dunes (Misra and Rajaguru 1989). The maximum transfer distance is not known, due to the absence of any detailed research in the Thar Desert to the east of the hills, although the African parallels indicate transport between 15 and $100 \mathrm{~km}$ (Petraglia et al. 2005, p. 208). A situation similar to that of the Rohri Hills is known at Ongar, near Hyderabad in lower Sindh (Pakistan), where Acheulean workshops were discovered lying on the top of flat limestone mesas (Figs. 7 and 8). These deposits, very rich in seams of excellent chert, were exploited throughout the entire Paleolithic period, from the Acheulean onward (Biagi 2006, 2008).

As far as these two latter cases in Sindh are concerned, there is no doubt that the abundance of excellent, workable raw material played a fundamental role in attracting prehistoric populations at least since the Acheulean period (Biagi and Cremaschi 1988, p. 425). The chert used by the earliest 


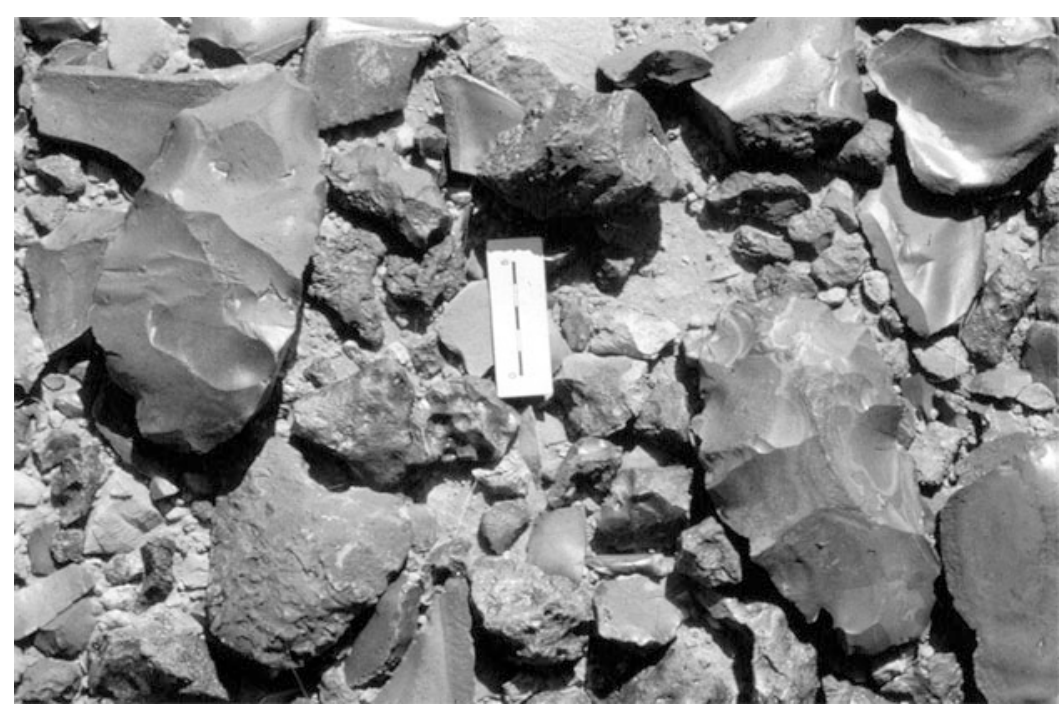

Fig. 6 Ziarāt Pir Shabān on the Rohri Hills (Sindh, Pakistan): Acheulean hand-axe rough-outs on the surface of workshop ZPS1 (Photograph by P. Biagi)

Paleolithic people was collected from large boulders or extracted from the top of the limestone terraces, as supported by the evidence from accurate surveys carried out along the top of the mesas that did not reveal any trace of Early Paleolithic mining activities.

As far as we know, the first Paleolithic chert quarries were opened by Acheulean populations, both in the Levant (Gopher and Barkai 2011) and Upper Egypt, much earlier than until recently supposed (Smolla 1987, p. 129). According to Vermeersch et al. (1995, p. 22), "a few kilometres south of the Dandara temple ........ hill was clearly subjected to chert extraction by Acheulian people," given the presence of an extractive pit discovered during the excavation of a small trench in an area rich in Late Acheulean tools. In contrast, almost nothing is known of Acheulean raw material procurement systems in this region, which yielded abundant traces of Middle and Upper Paleolithic flint-mining activities (Vermeersch et al 1997, p. 191).

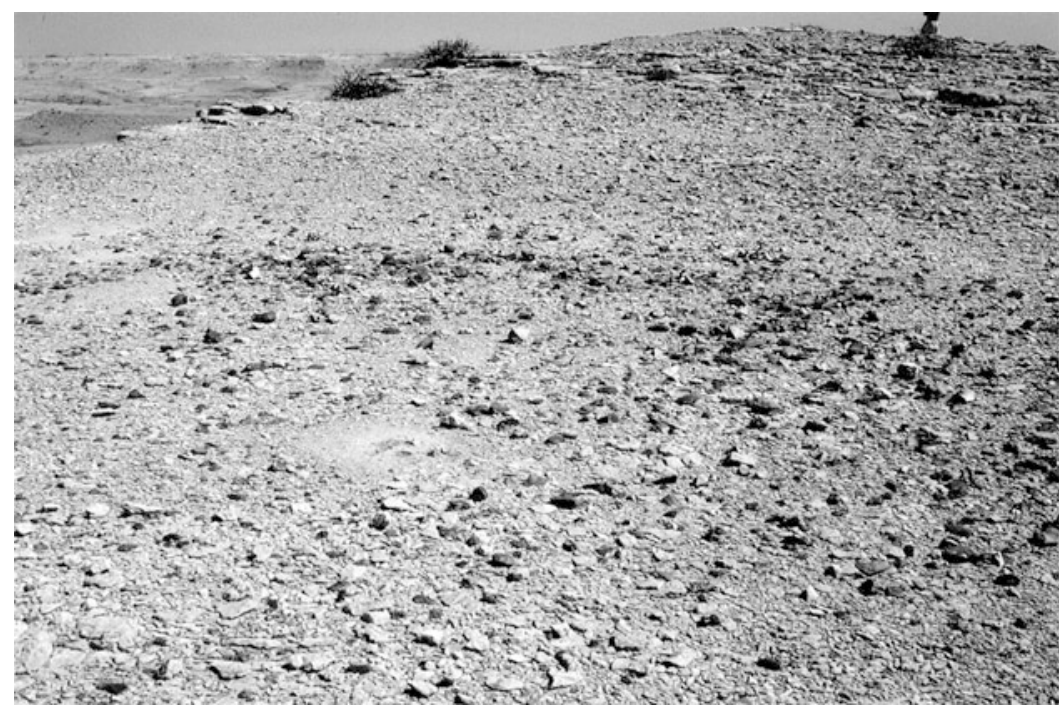

Fig. 7 Ongar (Sindh, Pakistan): C-shaped Acheulean chert factory area (Photograph by P. Biagi) 


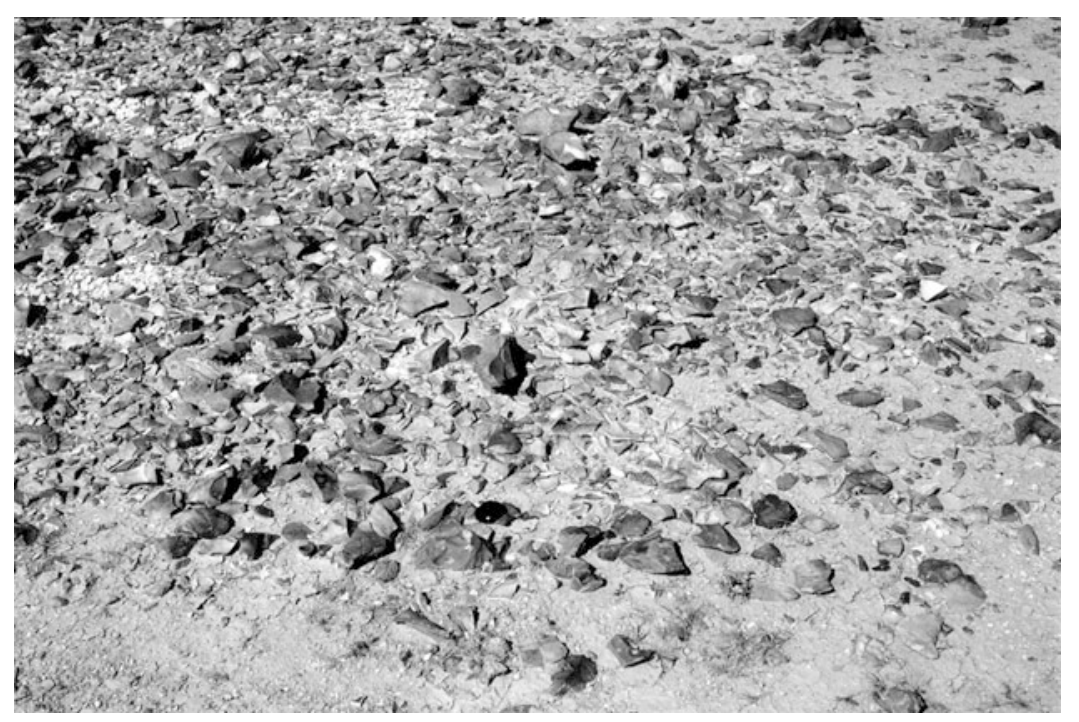

Fig. 8 Ongar (Sindh, Pakistan): In situ chert flakes concentration in an Acheulean workshop (Photograph by P. Biagi)

\section{Habitation and Other Structural Remains}

Early Paleolithic Mode 1 and 2 sites are often characterized by "concentrations of debris, ... which... have usually been interpreted to be the result of various processual phenomena" (Stiles 1998, p. 133). Only a few of them, of varied chronology, have provided us with complex archaeological evidence (see, for instance, Pappu 2001).

In Africa, we know that most of the earliest settlements were located in environments close to lake shores or, more commonly, along (former) river courses (Isaac 1976, Fig. 3.3) (Fig. 9). They have been interpreted as sites that are inhabited during only one season, whose remaining components, mainly lithic artifacts and bones, show they had been planned (Binford 1989a, p. 469). The 1.75-Myr-old Mode 1 site of DK, in Lower Bed I of the Olduvai Gorge (Leakey 1971, p. 24, Fig. 7), yielded evident traces of man-made features, the most important of which consists of a circular structure of lava blocks, some $4.5 \mathrm{~m}$ in diameter (Fig. 10), that the excavator interpreted as

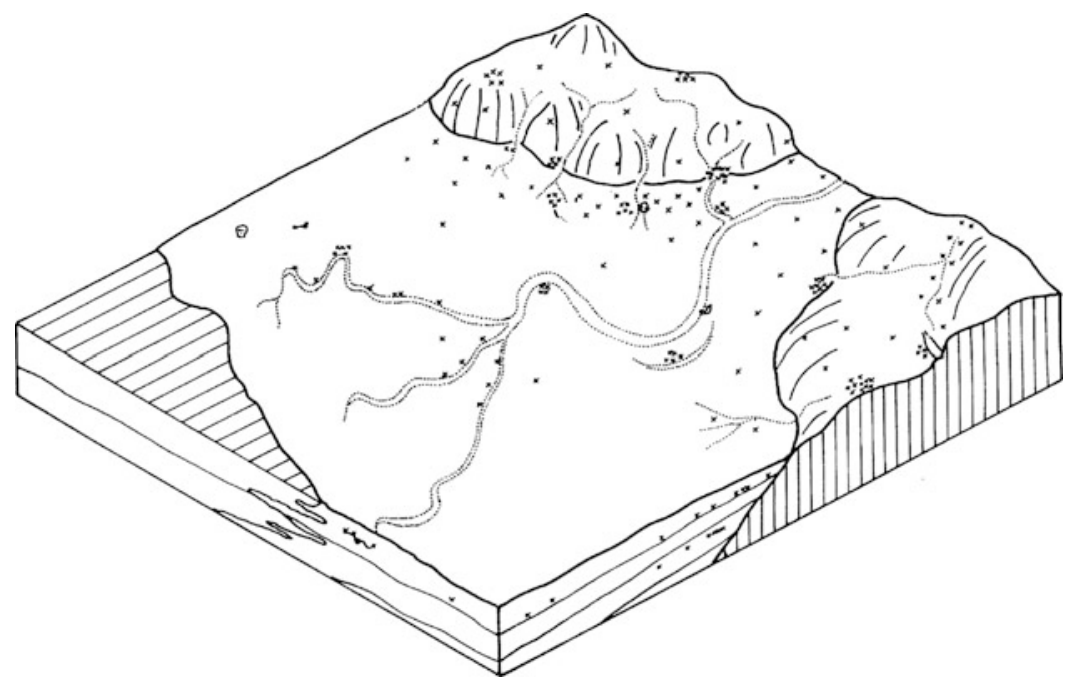

Fig. 9 Schematic representation of a portion of landscape frequented by tool-using hominids, with the locus of discarded artifacts marked X (After Isaac 1976, Fig. 3.3) 


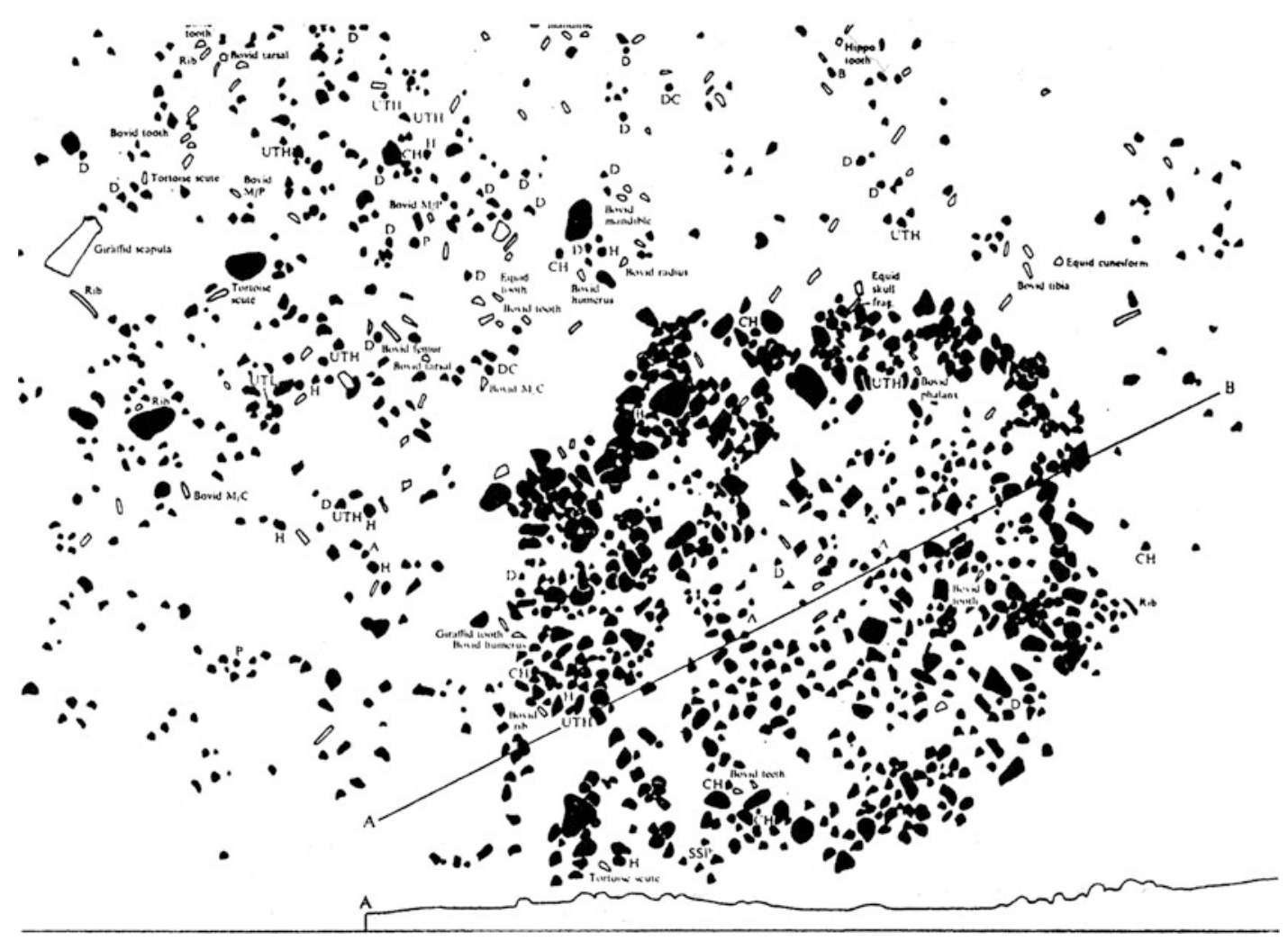

Fig. 10 Olduvai Gorge, site DK (Tanzania): Plan of the stone circle and the remains of the occupation surface: Stone artifacts shown in black, bones in outline (After Leakey 1971, Fig. 7)

resembling "temporary structures often made by present-day nomadic peoples who build a low stone wall round their dwellings to serve either as windbreak or as a base to support upright branches which are over and covered with either skin or grass" (Leakey 1971, p. 24).

The excavations carried out at Gomboré I, another Mode 1 site located at Melka Konturé in Ethiopia, brought to light a $230 \mathrm{~m}^{2}$ living floor composed of rounded pebbles and rich in stone tools and faunal remains, with a central empty space of some $10 \mathrm{~m}^{2}$. The settlement, which has been dated at some $1.6 \mathrm{Myr}$ ago, yielded a "higher platform ... that . . could have been roughly adapted for a shelter made of branches and animal skins" (Chavaillon 2004, p. 263). The research carried out at this site revealed the occurrence of "small stone circles aligned north-south in the eastern sector ... whose ... external diameter ... varies from 20 to $40 \mathrm{~cm}$," which were interpreted as possible "wedging stones for pegs set in rather hard soil" (Chavaillon and Chavaillon 2004, p. 448), similar to those recorded from Garba XII in the same region. Recent radiometric dates obtained from a few Early Paleolithic localities in the area revealed a sequence of habitation covering a long period comprised between 1.7 and 0.7 Myr ago (Morgan et al. 2012, p. 108).

Among the Mode 2 sites, extremely interesting and perfectly preserved remains were brought to light at Isernia La Pineta in Molise (Southern Italy). The chronology of this site is still rather controversial (Mussi 2001, p. 44), although the new radiometric dates indicate that the locality extends over an area of some $30,000 \mathrm{~m}^{2}$ and is some 0.60 million years old (Coltorti et al. 2005, p. 19), roughly contemporary with Notarchirico in the same region of central Italy (Orain et al. 2013). It yielded traces of four different occupation layers from which more than 10,000 lithic artifacts, chipped from different raw materials, including limestone and chert from diverse sources, were collected (Peretto 1994a). The site was located along the shores of a lake basin that was later buried 


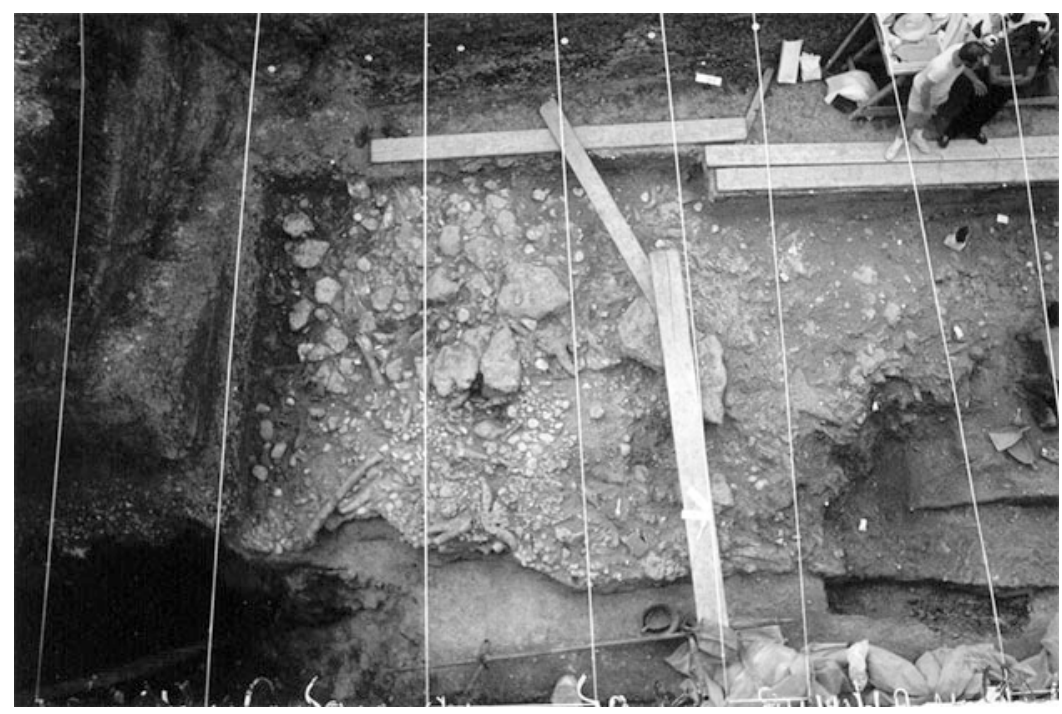

Fig. 11 La Pineta (Isernia, Southern Italy): A general view of the semicircular animal bones and material culture remains concentration surrounded by limestone boulders, discovered in 1980 (Photograph by P. Biagi)

by fluvial sediments. The most interesting structural remains were discovered during the beginning of the excavations, when an accumulation of animal bones and stone tools was uncovered on an almost semicircular paleosurface that was very rich in remains of Bison skulls and horns and Rhinoceros cranial bones and was delimited by large, travertine boulders (Giusberti et al. 1983, p. 100) (Figs. 11, 12 and 13). These discoveries might help interpret the spatial variability and activities carried out within this settlement site (Bartram et al. 1991). Remarkable differences have been noted among the lithic assemblages excavated in different areas of the site, both in the raw material employed for producing artifacts and in the typology and dimension of the stone tools (Fig. 14) (Peretto 1983, p. 81). For example, while flint was mainly used to obtain flakes, limestone was employed for the production of pebble tools, often characterized by the removal of just a few flakes from the distal edge (Peretto 1994b). Traceological studies and the experimental

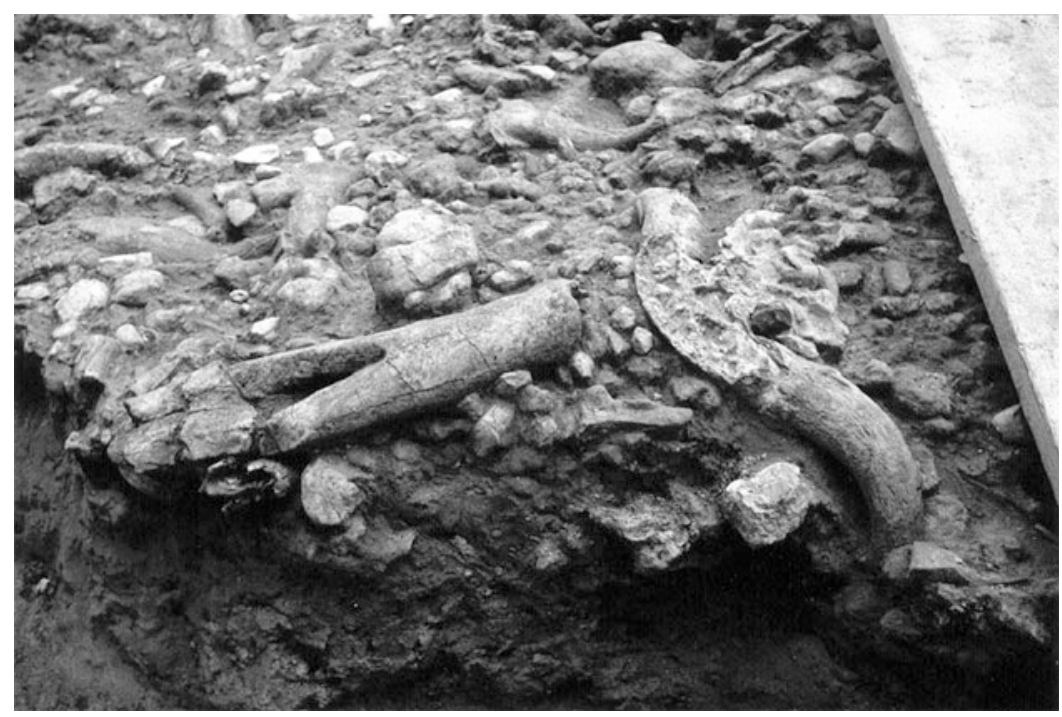

Fig. 12 La Pineta (Isernia, Southern Italy): Bison skull and long bone fragment from the main semicircular concentration discovered in 1980 (Photograph by P. Biagi) 


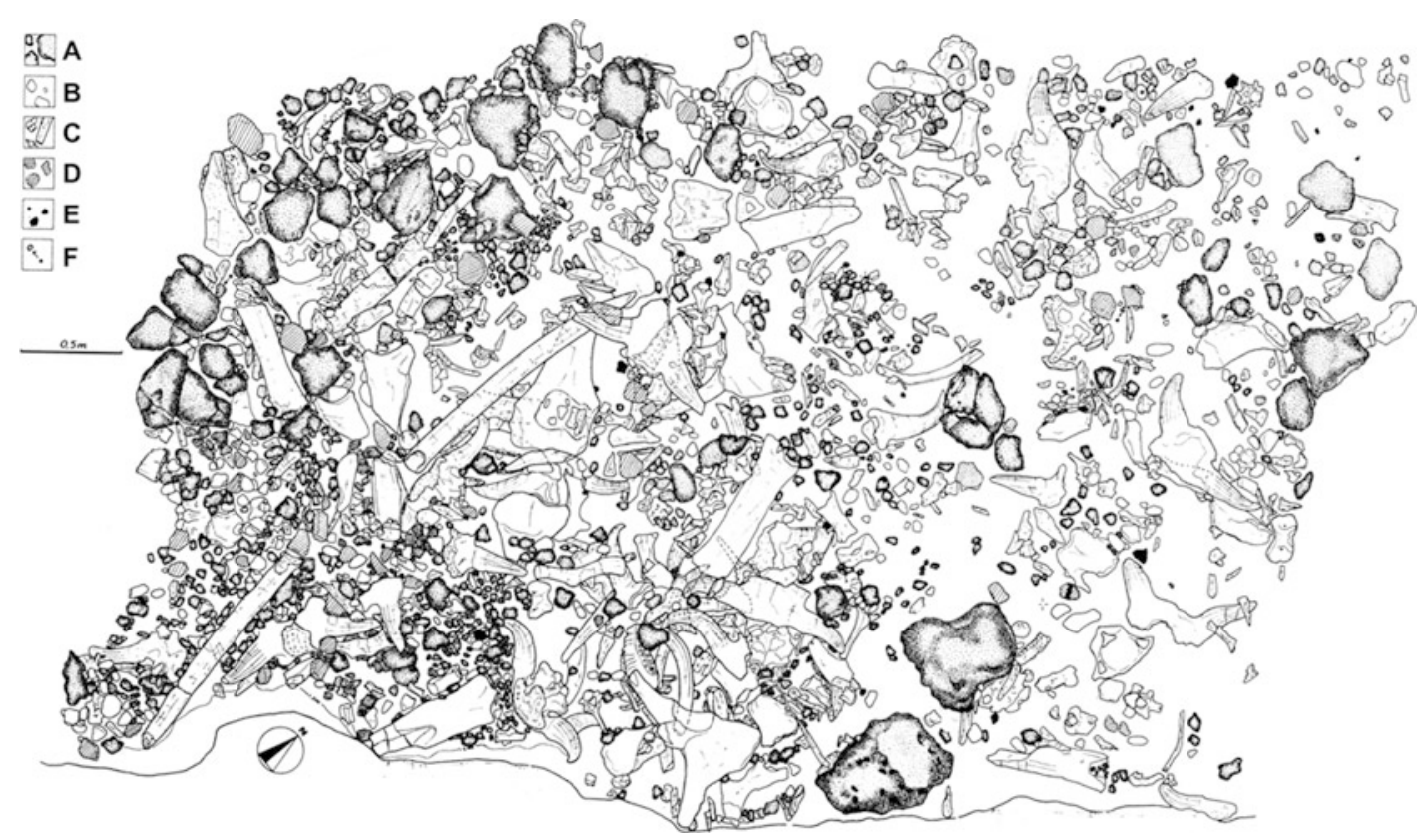

Fig. 13 La Pineta (Isernia, Southern Italy): Plan of the concentration of Fig. 11: a travertine, b pebbles, c faunal remains, d limestone tools, e flint tools, f red lacquerings (After Giusberti et al. 1983)

reproduction of the tool types and their chaine operatoire have shown that small flakes were the most important tools of the Isernia inhabitants, while denticulates that represent some $90 \%$ of the total assemblage are in effect only core waste residuals (Crovetto et al. 1993).

In central Italy, an interesting Mode 2 site dated to slightly later than $0.5 \mathrm{Myr}$ ago, and with an assemblage consisting of both elephant long bones and stone bifacial hand axes, has been excavated at Fontana Ranuccio (Biddittu et al. 1979). The presence of bone hand axes is unique to the area (Biddittu 1982), where they become increasingly more common at the slightly later Mode 2 sites, like Castel di Guido in Latium (Radmilli and Boschian 1996), where the use of elephant carcass bones for making tools has been analyzed in detail (Saccà 2012).

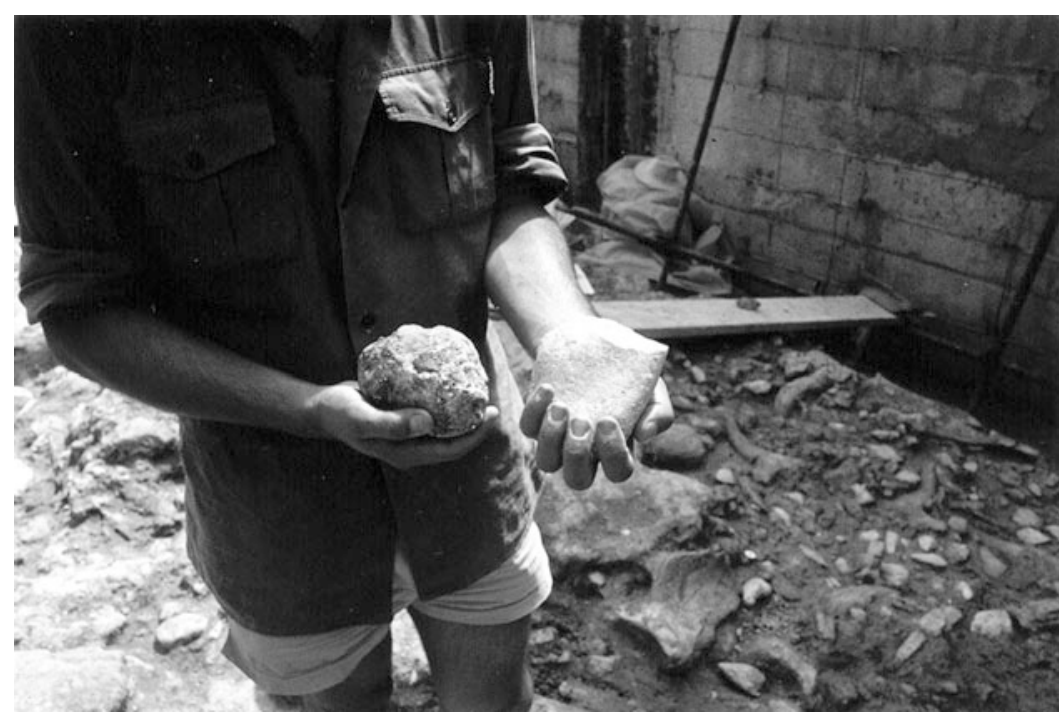

Fig. 14 La Pineta (Isernia, Southern Italy): Limestone choppers from the surface of the main semicircular concentration (Photograph by P. Biagi) 


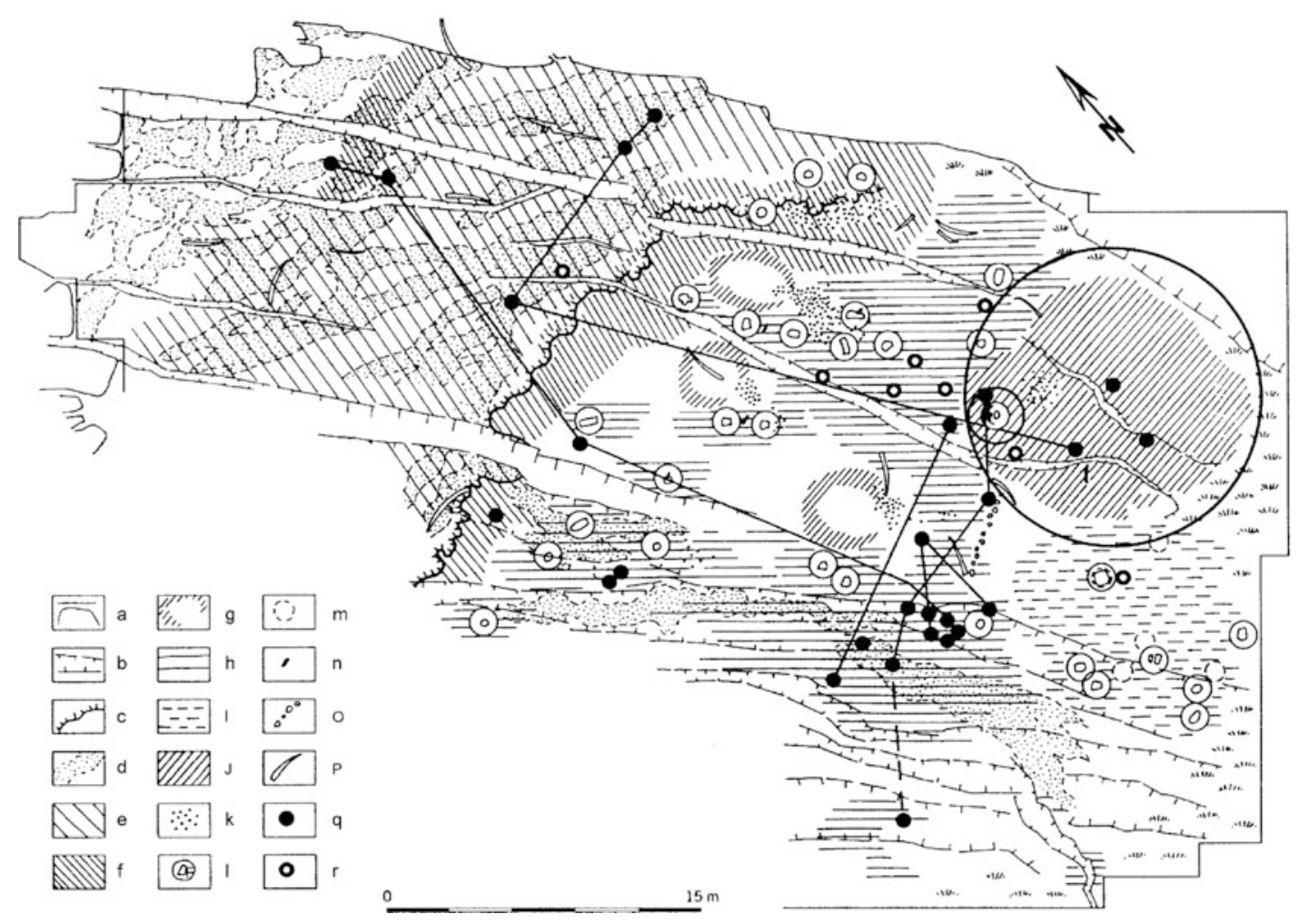

Fig. 15 Bilzingsleben (Germany): Plan of the structuration of the Early Paleolithic camp: a limits of the excavated area, $\mathbf{b}$ geological fault lines, $\mathbf{c}$ shoreline, $\mathbf{d}$ sandy travertine sediments, $\mathbf{e}$ alluvial fan, $\mathbf{f}$ activity area at the lake shore, $\mathbf{g}$ outlines of living structures, $\mathbf{h}$ workshop areas, $\mathbf{i}$ special workshop area with traces of fire use, $\mathbf{j}$ circular paved area, $\mathbf{k}$ charcoal, $\mathbf{l}$ bone anvils, $\mathbf{m}$ stone with traces of heat, $\mathbf{n}$ bones with intentional markings, $\mathbf{o}$ linear arrangement of stones, $\mathbf{p}$ elephant tusk, q human skull fragments, $\mathbf{r}$ human tooth (After Mania and Mania 2005, Fig. 7.1)

Moving westward, the importance of the remains of structures brought to light by H. de Lumley (1966) at Terra Amata, near Nice, in Provence, is represented by a shallow, oval-shaped hut floor attributed to a Mode 2 group of people who inhabited the region around $0.4 \mathrm{Myr}$ ago. Apart from the exceptional discovery of an almost "intact" habitation structure, the site is important because it yielded the first evident traces of a hearth indicating the use of fire by Paleolithic humans in Europe (de Lumley and de Lumley 2011, p. 41). Traces of fire that have long been suggested from a few Lower Pleistocene sites in East Africa (Clark and Harris 1985; Perlès 1977) are known since some 0.8 Myr ago in Israel (Goren-Inbar et al. 2004), although the reanalysis of 30 Paleolithic sites made a few years before had suggested that controlled fires are not earlier than $0.3 \mathrm{Myr}$ ago, most probably associated with very late Homo erectus (James 1996, p. 66) whether this taxonomy is still acceptable according to the new findings (Wagner et al. 2007).

The site of Steinrinne near Bilzingsleben, in central Germany, is of extreme importance for the study of Mode 2 hominids, although the interpretation of its stratigraphy, some $1 \mathrm{~m}$ thick, is still debated (Mania and Mania 2005; Müller and Pasda 2011), as well as its chronology, which is referred, according to the different authors, either to $0.42-0.35 \mathrm{Myr}$ ago or 0.25-0.20 Myr ago. The remains of three circular hut foundations, 3-4 m in diameter, with entrances systematically facing southeast and with workshop areas and fireplaces, have been discovered at this camp, dated to some $0.37 \mathrm{Myr}$ ago (Fig. 15). The importance of this site is indicated by the occurrence of the earliest so far known intentionally decorated bone objects that suggest "non-utilitarian behaviours ... connected to reflexive thinking" (Mania and Mania 2005, p. 110), as well as the indisputable traces 
of what is claimed to be a ritual paved area "with human skull fragments smashed in macerated condition" (Mania and Mania 2005, p. 113). According to Mania and Mania (2005, p. 114), these discoveries demonstrate that "Homo erectus was therefore a human being that had a fully developed mind and culture, capable in creating his own socio-cultural environment with living structures, the use of fire and special activity areas," although other authors prefer to attribute the finds to Homo heidelbergensis (Henke and Hardt 2012). This also finds confirmation in the traces of Acheulean "art" both in Africa (Bednarik 2003) and in the Indian subcontinent (Bednarik 1990).

Gran Dolina at Atapuerca in Spain is an even earlier multilayered site, where some kind of ritual activity has been supposed to have taken place. The site yielded 150 human bone fragments, which have been attributed to four individuals, classified into the new form Homo antecessor. Some of the hominid remains from Layer TD6, datable to at least 0.78 Myr ago (Falguères et al. 1999), "show clear cut marks which have been interpreted as evidence of cannibalism" (Mosquera Martínez 1998, p. 17). The chipped stone assemblage from this layer is characterized by relatively small artifacts, among which are utilized flakes, scrapers, denticulates, debitage flakelets, and byproducts suggesting the presence of a living floor where different activities had been performed (Carbonell et al. 1999).

Returning to Mediterranean France, this region is very rich in Lower Paleolithic sites, both open air and in caves. Among the latter, the internal deposits of Lazaret Cave (de Lumley 1969), a late Mode 2 Acheulean site attributed to some $0.12 \mathrm{Myr}$ ago, yielded traces of a unique hut structure that has been reconstructed, thanks to the occurrence of stone walls, fireplaces, and "masses of seaweeds possibly used as bedding for site occupants" (Mellars 1995, p. 285). Although this site does not represent the earliest known evidence of cave structural remains in Eurasia, given the traces of much older man-made stonewalls in China (Fang et al. 2004, Fig. 3) and Central Europe (Cyrek 2003, Fig. 6), Lazaret is the only one from which a detailed reconstruction of the events that took place inside the cave in Late Acheulean times has so far been possible (de Lumley and de Lumley 2011, p. 54).

\section{Hunting Weapons}

Although, as mentioned earlier, the excavations carried out at Terra Amata in the 1960s had already revealed the presence of one single fireplace, the almost contemporary hunting site of Schöningen, in North Germany, yielded not only the remains of four hearths, one of which is some $1 \mathrm{~m}$ in diameter, but even a charred wooden stick, which might "have functioned as a firehook to feed the fire as well as a spit to roast, and also smoke, strips or pieces of meat" (Thieme 2005, p. 127). This site is extremely important because of the occurrence of both the hunting weapons and the other wooden tools brought to light since 1994, which have radically revolutionized our view of the hunting methods and strategies followed by these hominids. The widely accepted view that early Homo was unable to conceive and construct throwing weapons is contradicted by the discovery of sophisticated spears, longer than $2 \mathrm{~m}$, which suggest a long tradition in wood shaping and weapon craftsmanship showing that, in contrast to what was previously supposed, this species had already acquired that complex "sequence pattern of behavioural complexes" (Laughlin 1968, p. 305) commonly labeled hunting, which represent "a way of life ... that ... has dominated the course of human evolution for hundreds of thousands of years" (Washburn and Lancaster 1968, p. 293). More precisely, "Homo erectus in the Middle Pleistocene was fully capable of organising, coordinating and successfully executing the hunting of big game animals in a group using longdistance weapons" (Thieme 2005, p. 127). Although the Schöningen specimens are not the only 
wooden pointed tools so far recovered from an Early Paleolithic site in Europe (Conard 2007, p. 2008), they undoubtedly represent the best preserved specimens discovered within a horse-hunting camp, a surface of some $3,500 \mathrm{~m}^{2}$ of which has already been excavated.

Furthermore, it is important to point out that already in the 1980 s, Isaac $(1984$, p. 17) had considered the use of throwing weapons by early hominids when he wrote "if the Lower Pleistocene tool-making hominids were hunting with equipment, they must have been using spears without stone tips (i.e. pointed staves or horns on staves), clubs, and, perhaps most important of all, thrown sticks and stones," given that "none of the flaked stone artefacts can plausibly be regarded as "weapons"” (!). In effect, it has been widely demonstrated that stone hand axes and cleavers (see, for instance, Gilead 1973) are excellent butchering tools, but not hunting weapons, and, in particular, that "the sinuous retouched edge of a hand-axe retains its meat-cutting efficiency longer than a plain flake edge" (Isaac 1984, p. 15).

\section{Conclusion}

Apart from the factors mentioned in the introduction, there are many others that make remains of early structures difficult to interpret. Among these are (1) the impossibility of "detailed" radiometric dating of the events that took place at short-term habitation sites, given that hunters periodically moved from site to site following their subsistence strategies (Binford 1978a, 1980), and (2) the difficulty of proving the supposed contemporaneousness of the structural remains within an apparently "homogeneous" area (Binford 1982). This is true even though it is widely assumed that "in inspecting the contents of a single structure, we can be fairly confident that the associated assemblage was all in use at one time, if not made at the same time" (Deetz 1968, p. 283). Besides the two above-mentioned factors, there are three others of major importance regarding (1) the complete excavation of an occupation unit, an enterprise that has been successfully undertaken only on very few occasions (Clark 1968, p. 277), (2) the functional nature of the (seasonal) site itself (Hehmsoth-Le Mouël 1999, p. 81), and (3) the eventual impact of scavengers on the bone remains originated by human activity (Binford et al. 1988).

With the exception of a limited number of cases reported by Clark for East Africa, and a few others which have been described in the preceding chapters, most sites are characterized by more or less dense concentrations of stone artifacts and bones, often closely related to each other (Binford 1989b, p. 459) although differently disposed according to the activities performed (Stevenson 1991, p. 280), reflecting "a complex system of extraction, manufacture, transport, use, resharpening, re-use, renewed transport and eventual discard" (Isaac 1986, Fig. 15.6). Often, these have been subjected to a certain degree of weathering or represent a (complicated) sequence of depositional events that took place over a period of millennia, forming archaeological palimpsests (Hosfield 2005). Isaac (1968, p. 255) classified such concentrations in three main categories according to the vertical and/or horizontal diffusion of the stone tools. The first two of these "represent sporadic, intermittent occupations of great duration," while the third "can probably be interpreted as fairly stable 'home base."”

Finally, ethnographic analogies are sometimes uncritically accepted by both archaeologists and anthropologists, who often believe "that modern representatives of past stages of cultural development exist" (Freeman 1968, p. 263), sometimes they are simply unaccepted, considered to be unreliable and nonscientific (Hodder 1982, p. 14), even though "any consideration of the implications for archeological interpretation of new ethnographic data ... requires an examination of the 
general relationships between ethnographic observations and archeological reasoning" (Binford 1968).

\section{Cross-References}

Adaptations, Frontiers, and New Territories

- Archaeology

- Charles Darwin, Paleoanthropology, and the Modern Synthesis

- Cultural Evolution in Africa and Eurasia During the Middle and Late Pleistocene

- Defining Homo erectus

- Defining the Genus Homo

- Historical Overview of Paleoanthropological Research

- Homo ergaster and Its Contemporaries

- Neanderthals and Their Contemporaries

- Origin of Modern Humans

- Overview of Paleolithic Archeology

\section{References}

Agustí J, Oms O, Parés JM, Martínez-Navarro B, Turq A (2000) Dating and correlation of early human occupation in the Baza formation (Guadix-Baza Basin, SE Spain). In: Lordkipanidze D, Bar-Yosef O, Otte M (eds) Early humans at the Gates of Europe, vol 92. ERAUL, Liège, pp 113-122

Amirkhanov HA (1994) Research on the Palaeolithic and Neolithic of Hadramauth and Mahra. Arab Archaeol Epigr 5:217-228

Amirkhanov HA (2006) Stone Age of south Arabia. Nauka, Moscow (in Russian)

Andsky W Jr (2007) The application and disapplication of mass analysis in lithic debitage studies. J Archaeol Sci 34:392-402

Arzarello M, Marcolini F, Pavia G, Pavia M, Petronio C, Petrucci M, Rook L, Sardella R (2007) Evidence of earliest human occurrence in Europe: the site of Pirro Nord (Southern Italy). Naturwissenschaften 94:107-112

Arzarello M, Pavia G, Peretto C, Petronio C, Sardella R (2012) Evidence of an Early Pleistocene hominin presence at Pirro Nord (Apricena, Foggia, Southern Italy) P13 site. Quat Int 267:56-61

Ashton N, McNabb J (1993) Bifaces in perspective. In: Ashton N, David A (eds) Stories in stone, Lithic studies society occasional paper, vol 4. Lithic Studies Society, London, pp 182-191

Bartram LE, Kroll EM, Bunn HT (1991) Variability in camp structure and bone food refuse patterning at Kua San Hunter-Gatherer Camps. In: Kroll EM, Price TD (eds) The interpretation of archaeological spatial patterning. Plenum Press, New York/London, pp 77-148

Bar-Yosef O (1994) The Lower Palaeolithic of the near east. J World Prehistory 3(8):211-265. New York and London

Bar-Yosef O (1995) The Lower and Middle Palaeolithic in the Mediterranean Levant: chronology, and cultural entities. In: Ullrich $\mathrm{H}$ (ed) Man and environment in the Palaeolithic, vol 62. ERAUL, Liège, pp 247-264 
Bar-Yosef O, Belfer-Cohen A (2000) Early human dispersal: the unexplored constraint of African diseases. In: Lordkipanidze D, Bar-Yosef O, Otte M (eds) Early humans at the Gates of Europe, vol 92. ERAUL, Liège, pp 9-86

Bednarik RG (1990) An Acheulean haematite pebble with striations. Rock Art Res 7:75

Bednarik RG (2003) A figurine from the African Acheulian. Curr Anthropol 44(3):405-412

Bergman CA, Roberts MB, Collcutt S, Barlow P (1990) Refitting and spatial analysis of artefacts from quarry 2 at the Middle Pleistocene Acheulean site of Boxgrove, West Sussex, England. In: Cziesla E, Eickhoff S, Arts N, Winter D (eds) The big puzzle. International symposium on refitting stone artefacts. Holos, Bonn. Stud Modern Archaeol 1:265-281

Biagi P (2006) Ongar revisited. Sindhological Stud 21(1-2):5-25. Jamshoro

Biagi P (2008) The Palaeolithic settlement of Sindh (Pakistan): a review. Archäologische Mitteilungen aus Iran und Turan 40:1-26

Biagi P, Cremaschi M (1988) The early Palaeolithic sites of the Rohri Hills (Sind, Pakistan) and their environmental significance. World Archaeol 19(3):421-434

Biagi P, Kazi MM, Negrino F (1996) An Acheulean workshop at Ziarat Pir Shaban on the Rohri Hills, Sindh, Pakistan. South Asian Stud 12:49-62. Cambridge

Biddittu I (1982) Utilizzazione dell'osso nel Paleolitico inferiore italiano. Atti della XXIII Riunione Scientifica dell'Istituto Italiano di Preistoria e Protostoria. Firenze, pp 89-105

Biddittu I, Cassoli PF, Radicati di Brozolo F, Segre AG, Segre Naldini E, Villa I (1979) Anagni, a K-Ar dated Lower and Middle Pleistocene site, Central Italy: preliminary report. Quaternaria XXI:53-71. Rome

Binford SR (1968) Ethnographic data and understanding the Pleistocene. In: Lee RB, De Vore I (eds) Man the hunter. Aldine, New York, pp 274-275

Binford LR (1978a) Nunamiut Ethnoarchaeology. Academic, New York/San Francisco/London

Binford LR (1978b) Dimensional analysis of behavior and site structure: learning from an Eskimo Hunting Stand. Am Antiq 43(3):330-361

Binford LR (1980) Willow smoke and dog's tails: hunter-gatherer settlement systems and archaeological site formation. Am Antiq 45(1):4-20

Binford LR (1982) The archaeology of place. J Anthropol Archaeol 1:5-31

Binford LR (1989a) Isolating the transition to cultural adaptations: an organizational approach. In: Binford LR (ed) Debating archaeology. Academic, London, pp 464-481

Binford LR (1989b) Technology of early man: an organizational approach to the oldowan. In: Binford LR (ed) Debating archaeology. Academic, London, pp 437-463

Binford LR, Mills MGL, Stone NM (1988) Hyena scavenging behavior and its implications for the interpretation of Faunal assemblages from FLK22 (the Zinj Floor) at Olduvai Gorge. J Anthropol Archaeol 7:99-135

Bordes F (1968) The old Stone Age. Weidenfeld and Nicholson, London

Boucher de Perthes M (1864) Antiquites Celtiques et Antédeluviennes. Mémoire sur l'industrie primitive et les arts a leur origine. Part 3. Jung-Treuttel/Derache/Dumoulin/V. Didron, Paris

Braun DR, Christopher JN, Harris WK (2010) Africa and Asia: comparisons of the earliest archaeological evidences. In: Norton CJ, Braun DR (eds) Asian palaeoanthropology. From Africa to China and beyond. Springer, London/New York, pp 41-48

Broglio A (1998) Introduzione al Paleolitico. Laterza, Bari

Brown AG (1997) Alluvial geoarchaeology. Floodplain archaeology and environmental change. Cambridge University Press, Cambridge

Brumm A, Rainey A (2011) The Acheulean downunder: modern human "handaxes" from the Barkly Tableland of Northern Australia. Lithics 32:49-61 
Bunn H, Harris JWK, Isaac G, Kaufulu Z, Kroll E, Schick K, Toth N, Behrensmeyer AK (1980) FxJi50: an early Pleistocene site in northern Kenya. World Archaeol 12(2):109-136

Cachel S, Harris JWK (2007) The lifeways of Homo Erectus inferred from archaeology and evolutionary ecology: a perspective from East Africa. In: Petraglia MD, Korisettar R (eds) Early human behaviour in global context. The rise and diversity of the Lower Palaeolithic record. Routledge, London/New York, pp 104-129

Camps G (1979) Manuel de recherches préhistorique. Doin, Paris

Carbonell E, Garcia-Antón MD, Mallal C, Mosquera M, Ollé A, Rodriguez XP, Sohnouni M, Sole R, Vergès JM (1999) The TD6 level lithic industry from Dolina, Atapuerca (Burgos, Spain) production and use. J Hum Evol 37:653-693

Chauhan PR (2005) A review of the early Acheulean evidence from South Asia. Assemblage 8:1-21. Sheffield

Chauhan PR (2010) Comment on Lower and Early Middle Pleistocene Acheulian in the Indian subcontinent by Gaillard et al. (2009) Quaternary International. Quat Int 223-224:248-259

Chavaillon J (2004) Discovery, geological introduction and study of percussion material and tools on pebble. In: Chavaillon J, Piperno M (eds) Studies on the Early Palaeolithic site of Melka Konture, Ethiopia. Origines. Istituto Italiano di Preistoria e Protostoria, Firenze, pp 253-369

Chavaillon J, Chavaillon N (2004) Comments and conclusion on the lithic assemblage. In: Chavaillon J, Piperno M (eds) Studies on the Early Palaeolithic site of Melka Konture, Ethiopia. Origines. Istituto Italiano di Preistoria e Protostoria, Firenze, pp 437-448

Clark JD (1968) Studies of hunter-gatherers as an aid to the interpretation of prehistoric societies. In: Lee RB, De Vore I (eds) Man the hunter. Aldine, New York, pp 276-280

Clark JD (1994) The Acheulean industrial complex in Africa and elsewhere. In: Corruccini RS, Giocon RI (eds) Integrative paths to the past: paleoanthropological advances in honor of F. Clark Howell. Prentice Hall, Englewood Cliff, pp 451-469

Clark JD, Harris JWK (1985) Fire and its roles in early hominids lifeways. Afr Archaeol Rev 3:3-27

Coltorti M, Feraud G, Marzoli A, Pereto C, Ton-That T, Voinchet P, Bahain J-J, Minelli A, Thun Hohenstein U (2005) New 40Ar/39Ar, stratigraphic and palaeoclimatic data on the Isernia La Pineta lower Palaeolithic site, Molise, Italy. Quat Int 131:11-22

Conard N (2007) Cultural evolution in Africa and Eurasia during the middle and late pleistocene. In: Henke W, Tattersall I (eds) Handbook of paleoanthropology, vol III, Phylogeny of hominids. Springer, Berlin/Heidelberg/New York, pp 2001-2037

Cremaschi M, Negrino F (2002) The Frankincense road of Sumhuram: palaeoenvironmental and prehistorical background. In: Avanzini A (ed) Khor Rohri report 1. Arabia Antica, vol 1. Edizioni Plus, Università di Pisa, pp 325-363

Crovetto C, Ferrari F, Peretto C, Vianelo F (1993) La scheggiatura, descrizione degli insiemi, i rimontagli. In Peretto C (ed) Le Industrie Litiche del Giacimento Paleolitico di Isernia La Pineta la tipologia, le tracce di utilizzazione, la sperimentazione. Cosmo Iannone Editore, Isernia, pp 87-118

Cyrek K (2003) Biśnik cave: a reconstruction of the site's occupation in the context of environmental changes. Eurasian Prehistory 1(1):5-30

de Lumley H (1966) Les fouilles de Terra Amata à Nice. Premier résultats. Bulletin du Musée d'Anthropologie Préhistorique de Monaco 13:29-51

de Lumley H (1976) Les premières industries humaines en Provence. La Préhistoire Française 2(1):765-776. CNRS, Paris 
de Lumley H (1969) Une Cabane Acheuléenne dans la Grotte du Lazaret (Nice), Mémoires de la Société Préhistorique Française, vol 7. Paris

de Lumley H, de Lumley M-A (2011) Les Premières Peuplements de la Côte d'Azur et le la Ligurie. 1 Million d'Années sur les Rivages de la Méditerranée. Tome I - Le Paléolithique. Melis, Colomars

de Lumley H, Fournier A, Krzepowska J, Echassoux A (1988) L'industrie du Pléistocène inférieur de la Grotte du Vallonet, Roquebrune-Cap-Martin, Alpes Maritimes. L'Anthropologie 92:465-495

De Terra H, Paterson TT (1939) The Ice Age in the Indian Subcontinent and Associated Human Cultures with special reference to Jammu, Kashmir, Ladakh, Sind, Liddar and Central \& Peninsular India. Carnegie Institution, Washington

De Terra H, Movius HL (1943) Research on the Early Man in Burma. Trans Am Philos Soc. XXXII, part II, Philadelphia

Deetz JJF (1968) The social unit. In: Lee RB, De Vore I (eds) Man the hunter. Aldine, New York, pp 282-284

Desittere M (1988) Paletnologi e studi preistorici nell'Emilia Romagna dell'Ottocento. Musei Civici, Reggio Emilia

Domínguez-Rodrigo M (2002) Hunting and scavenging by early humans: the state of the debate. J World Prehistory 16(1):1-54

Draper N (1985) Back to the drawing board: a simplified approach to assemblage variability in the Early Palaeolithic. World Archaeol 17(1):3-19

Falguères C, Bahain JJ, Yokoyama Y, Arsuaga JL, de Bermudez Castro JM, Carbonell E, Bischoff JL, Dolo JM (1999) Earliest humans in Europe: the age of TD6 Gran Dolina, Atapuerca, Spain. J Hum Evol 37(3-4):343-352

Fang Y, Huang Y, Shen C (2004) Pebble semicircle structure from a Lower Palaeolithic site in southern China. Eurasian Prehistory 2(2):3-12

Figuier L (1870) L'Homme Primitif. L Hachette et Cie, Paris

Freeman LG Jr (1968) A theoretical framework for interpreting archaeological materials. In: Lee RB, De Vore I (eds) Man the hunter. Aldine, New York, pp 262-267

Gabunia M (2000) On ancient man in the volcanic mountainous regions of South Georgia. In: Lordkipanidze D, Bar-Yosef O, Otte M (eds) Early humans at the Gates of Europe, vol 92. ERAUL, Liège, pp 43-47

Gabunia LK, Jöris O, Justus A, Lordkipanidze D, Muschelišvili A, Nioradze M, Swisher CC III, Vekua AK, Bosinski G, Ferring RC, Majsuradze GM, Tvalčrelidze M (1999) Neue Hominidenfunde des Altpaläolitische Fundplatzes Dmanisi (Georgien, Kaukasus) im Kontext aktueller Grabungsergebnisse. Archäologisches Korrespondenzblatt 29:451-488. Cologne

Gaillard C, Mishra S, Singh M, Deo S, Abbas R (2010) Lower and middle Pleistocene Acheulian in the Indian Sub-continent. Quat Int 223-224:234-241

Gilead D (1973) Cleavers in Early Palaeolithic industries in Israel. Paléorient 1(1):73-86

Giusberti G, Guerreschi A, Peretto C (1983) Le strutture d'abitato dell'accampamento Paleolitico di Isernia La Pineta. Prime considerazioni. In: Isernia La Pineta. Un accampamento più antico di 700.000 anni. Calderini, Bologna, pp 95-103

Gopher A, Barkai R (2011) Sitting on the tailing piles: creating extraction landscapes in Middle Pleistocene quarry complexes in the Levant. World Archaeol 43(2):211-229

Goren-Inbar N, Alperson N, Kisler ME, Simchoni O, Melamed Y, Ben-Nun A, Werkel E (2004) Evidence of hominin control of fire at Gesher Benol Ya'aqov, Israel. Science 304(5671):725-727 
Gowlett JAJ (2005) Seeking the Palaeolithic individual in East Africa and Europe during the Lower-Middle Pleistocene. In: Gamble C, Porr M (eds) The hominid individual in context. Archaeological investigations of Lower and Middle Palaeolithic landscapes, locales and artefacts. Routledge, London/New York, pp 50-67

Gowlett JAJ (2009) Boucher de Perthes: pioneer of palaeolithic archaeology. Lithics 30:13-24

Graziosi P (1964) Italian expeditions to the Karakorum (K2) and Hindu Kush. Scientific reports. V - Prehistory-anthropology. Prehistoric research in northwestern Punjab, anthropological research in Chitral. EJ Brill, Leiden

Guidi A (1987) The development of prehistoric archaeology in Italy: a short review. Acta Archaeol 58:237-247

Hansen PV, Madsen B (1983) Flint axe manufacture in the Neolithic. An experimental investigation of a flint axe manufacture site at Hastrup Vænget, East Zealand. J Danish Archaeol 2:43-59

Hassan FA (1988) Prolegomena to a grammatical theory of lithic artifacts. World Archaeol 19(3):281-296

Hehmsoth-Le Mouël M (1999) The presence of intact, complete artifacts in archaeological sites: indicators of a rupture in the way of life? In: Owen LR, Porr M (eds) Ethno-analogy and the reconstruction of prehistoric artefact use and production. Urgeschichtliche Materialhefte, vol 14. Mo Vince, Tübingen, pp 75-90

Henke W, Hardt T (2012) The Genus Homo; origin, speciation and dispersal. In: Condemi S, Wenige G-C (eds) Continuity and discontinuity in the peopling of Europe; one hundred fifty years of Neanderthal study. Vertebrate paleobiology and paleoanthropology. Springer, Dordrecht/Heidelberg/London/New York, pp 17-46

Hodder I (1982) The present past. An introduction to anthropology for archaeologists. Batsford, London

Hopkinson T, White MJ (2005) The Acheulean handaxe: structure and agency in the Palaeolithic. In: Gamble C, Porr M (eds) The hominid individual in context. Archaeological investigations of Lower and Middle Palaeolithic landscapes, locales and artefacts. Routledge, London/New York, pp 13-28

Hosfield R (2005) Individuals among palimpsest data. Fluvial landscapes in Southern England. In: Gamble C, Porr M (eds) The Hominid individual in context. Archaeological investigations of Lower and Middle Palaeolithic landscapes, locales and artefacts. Routledge, London/New York, pp 220-243

Isaac GLI (1967) Towards the interpretation of occupation debris: some experiments and observations. Kroeber Anthropol Soc Pap 37:31-57

Isaac GL (1968) Traces of Pleistocene hunters: an East African example. In: Lee RB, De Vore I (eds) Man the hunter. Aldine, New York, pp 253-261

Isaac GLI (1972) Early phases of human behaviour: models in Lower Palaeolithic archaeology. In: Clarke DL (ed) Models in archaeology. Methuen, London, pp 167-199

Isaac GLI (1976) Early hominids in action: a commentary on the contribution of archaeology to understand the fossil record in East Africa. Yearb Phys Anthropol for 1975:19-35

Isaac GLI (1977) Olorgesailie: archaeological studies of a middle Pleistocene lake basin. University of Chicago Press, Chicago

Isaac GLI (1984) The archaeology of human origins: studies of the Lower Pleistocene in East Africa 1971-1981. In: Wendorf F, Close A (eds) Advances in old world archaeology, vol 3. Academic, New York, pp 1-87 
Isaac GLI (1986) Foundation stones: early artefacts as indicators of activities and abilities. In: Bailey GN, Callow P (eds) Stone Age prehistory. Cambridge University Press, Cambridge, pp 221-241

James SR (1996) Early Hominid use of fire: recent approaches and methods for evaluation of the evidence. In: Bar-Yosef O, Cavalli-Sforza LL, March RJ, Piperno M (eds) The Lower and Middle Palaeolithic. XIII international congress of prehistoric and protohistoric sciences Forlì - Italia - 8/14 September 1996. Section 5 - The Lower and Middle Palaeolithic. A.B.A. C.O., Forlì, pp 65-76

Keeley LH (1991) Tool use and spatial patterning. Complications and solutions. In: Kroll EM, Price TD (eds) The interpretation of archaeological spatial patterning. Plenum Press, New York/ London, pp 257-268

Lamdin-Whymark H (2009) Sir John Evans: experimental flint knapping and the origin of lithic research. Lithics 30:45-52

Laughlin WS (1968) Hunting: an integrating biobehavior system and its evolutionary importance. In: Lee RB, De Vore I (eds) Man the hunter. Aldine, New York, pp 304-320

Leakey MD (1971) Olduvai Gorge. Excavations in beds I \& II 1960-1963. Cambridge University Press, Cambridge

Ling V (2011) The Lower Palaeolithic colonisation of Europe: antiquity, magnitude, permanency and cognition. BAR international series 2316. Archaeo Press, Oxford

Lordkipanidze D, Vekua A (2006) Unique discoveries of ancient hominid fossils in Dmanisi (Eastern Georgia). Archaeol Caucasia 1:55-64

Lubbock J (1870) The origin of civilisation and the primitive condition of man. Longmans, Green, London

Madsen B, Goren-Inbar N (2004) Acheulian giant core technology and beyond: an archaeological and experimental case study. Eurasian Prehistory 2(4):3-52

Magnani P (ed) (2007) Gaetano Chierici. Tutti gli Scritti di Archeologia. Diabasis, Reggio Emilia

Mania D, Mania U (2005) The natural and socio-cultural environment of Homo erectus at Bilzingsleben, Germany. In: Gamble C, Porr M (eds) The hominid individual in context. Archaeological investigations of Lower and Middle Palaeolithic landscapes, locales and artefacts. Routledge, London/New York, pp 98-114

McNabb J (2009) The knight, the grocer, and the chocolate brownies; Joseph Prestwich, Benjamin Harrison and the second "antiquity of man" debate. In: Hosfield RT, Wenban-Smith FF, Pope MI (eds) Great prehistorians: 150 years of palaeolithic research, 1859-2009. Lithic Studies Society, London, Lithics 30:97-115

McNabb J, Binyon F, Hazelwood L (2004) The large cutting tools from the South African Acheulean and the question of social traditions. Curr Anthropol 45(5):653-677

Mellars P (1995) The Neanderthal legacy. An archaeological perspective from Western Europe. Princeton University Press, Princeton

Misra VN, Rajaguru SN (1989) Palaeoenvironments and prehistory of the Thar Desert, Rajasthan, India. In: Frifelt K, Sørensen R (eds) South Asian archaeology 1985. Scandinavian Institute of Asian studies occasional papers 4. Århus, pp 296-320

Morgan LE, Renne PR, Kieffer G, Piperno M, Gallotti R, Raynal J-P (2012) A chronological framework for a long and persistent archaeological record: Melka Kunture, Ethiopia. J Hum Evol 62:104-115

Mosquera Martínez M (1998) Differential raw material use in the Middle Pleistocene of Spain. Evidence from Sierra de Atapuerca, Torralba, Ambrona and Aridos. Camb Archaeol J 8(1):15-28 
Movius HL Jr (1948) The Lower Palaeolithic cultures of Southern and Eastern Asia. Trans Am Philos Soc New Series 38(4):330-420

Movius HL Jr (1944) Early man and Pleistocene stratigraphy in Southern and Eastern Asia. Papers of the Peabody Museum of American Archaeology and Ethnology, Harvard University. XIX (3):7-125

Müller W, Pasda C (2011) Site formation and faunal remains of the Middle Pleistocene site Bilzingsleben. Quartär 58:25-49

Mussi M (2001) Earliest Italy. An overview of the Italian Paleolithic and Mesolithic. Kluwer Academic/Plenum, New York/Boston/Dordrecht/London/Moscow

Nioradze M, Nioradze G (2011) Early Palaeolithic site of Dmanisi and its lithic industry. Archaeol Caucasus 4:103-147 (in Russian)

Orain R, Lebreton V, Russo Ermolli E, Sémah S, Shao Q, Bahain J-J, Thun Hohenstein U, Peretto C (2013) Hominin responses to environmental changes during the Middle Pleistocene in Central and Southern Italy. Clim Past 9:687-697

Otte M (2000) Recherches récentes sur le Paléolithique Inférieur d'Asie. In: Lordkipanidze D, BarYosef O, Otte M (eds) Early humans at the Gates of Europe, vol 92. ERAUL, Liège, pp 107-111

Otte M (2010) Before Levallois. Quat Int 223-224:273-280

Paddayya K, Blackwell BAB, Shaldiyal R, Petraglia MD, Fevrier S, Chaderton DA II, Blickstein JIB, Skinner AR (2002) Recent findings of the Acheulian of the Hunsgi and Baichbal valleys, Karnataka, with special reference to the Isampur excavation and its dating. Curr Sci 83(5):641-647

Pappu RS (2001) Acheulian culture in Peninsular India. DK Printworld, New Delhi

Paterson TT, Drummond HJH (1962) Soan the Palaeolithic of Pakistan. Department of Archaeology, Government of Pakistan, Ferozsons, Karachi

Peretto C (1983) Le industrie litiche di Isernia La Pineta. In: Isernia La Pineta un accampamento più antico di 700.000 anni. Calderini, Bologna, pp 81-93

Peretto C (1994a) Il Giacimento Paleolitico. In: Peretto C (ed) Le industrie litiche del giacimento Paleolitico di Isernia La Pineta: La tipologia, le tracce di utilizzazione, la sperimentazione. Cosmo Iannone, Isernia, pp 29-40

Peretto C (1994b) Le industrie liitche. Conclusioni di carattere generale e riassuntivo. In: Peretto C (ed) Le industrie litiche del giacimento Paleolitico di Isernia La Pineta: La tipologia, le tracce di utilizzazione, la sperimentazione. Cosmo Iannone, Iserbnia, pp 453-460

Peretto C, Amore FO, Antoniazzi A, Bahain J-J, Cattani L, Esposito P, Falguères C, Gagnepain J, Hedley J, Laurent M, Lebreton L, Longo L, Milliken S, Vanucci S, Verrgés JM, Wagner JJ, Yokoyama Y (1999) L'industrie lithique de Ca' Belvedere di Monte Poggiolo. Stratigraphie, matière première, typologie, remontages et traces d'utilisation. L'Anthropologie 102:1-120

Perlès C (1977) Préhistoire du feu. Masson, Paris

Petraglia MD (1998) The Lower Palaeolithic of India and its bearing on the Asian record. In: Petraglia MD, Korisettar R (eds) Early human behaviour in global context. The rise and discovery of the Lower Palaeolithic record. One world archaeology. Unwin Hyman, Boston/ Sidney/Washington, pp 343-390

Petraglia MD (2003) The Lower Palaeolithic of the Arabian Peninsula: occupations, adaptations, and dispersal. J World Prehistory 17(2):141-179. New York/London

Petraglia MD (2007) Mind the gap: factoring the Arabian peninsula and the Indian subcontinent into Out of Africa models. In: Mellars P, Boyle K, Bar-Yosef O, Stringer C (eds) The human revolution revisited. McDonald Institute Archaeological, Cambridge, pp 671-684 
Petraglia MD, Shipton C, Paddaya K (2005) Life and mind in the Acheulean. A case study from India. In: Gamble C, Porr M (eds) The hominid individual in context. Archaeological investigations of Lower and Middle Palaeolithic landscapes, locales and artefacts. Routledge, London/ New York, pp 197-219

Pigorini L (1866) Paleoetnologia. Annuario Scientifico Industriale II:211-250

Porr M (2005) The making of the biface and the making of the individual. In: Gamble C, Porr M (eds) The hominid individual in context. Archaeological investigations of Lower and Middle Palaeolithic landscapes, locales and artefacts. Routledge, London/New York, pp 68-80

Prestwich J (1860) On the occurrence of flint implements, associated with the remains of animals of extinct species in beds of the late geological period, in France at Amiens and Abbeville, and in England at Hoxne. Philos Trans R Soc Lond 150:277-317

Radmilli AM, Boschian G (1996) Gli scavi a Castel di Guido. Origines. Istituto Italiano di Preistoria e Protostoria, Firenze

Regazzoni I (1885) Paleoetnologia. Hoepli, Milano/Napoli/Pisa

Rightmire P (2007) Later Middle Pleistocene Homo. In: Henke W, Tattersall I (eds) Handbook of paleoanthropology, vol III, Phylogeny of hominids. Springer, Berlin/Heidelberg/New York, pp 1695-1715

Roebroeks W, van Kolfschoten T (1994) The earliest occupation of Europe. Antiquity 68(260):489-503. Cambridge

Rose JI, Petraglia MD (2009) Tracking the origin and evolution of human population in Arabia. In: Petraglia MD, Rose JI (eds) The evolution of human populations in Arabia. Springer, Netherlands, pp 1-12

Saccà D (2012) Taphonomy of Palaeloxodon antiquus at Castel di Guido (Rome, Italy): proboscidean carcass exploitation in Lower Palaeolithic. Quat Int 276-277:24-71

Santonja M, Villa P (1990) The Lower Palaeolithic of Spain and Portugal. J World Prehistory 4(1):45-94. New York and London

Sinclair A, McNabb J (2005) All in a day's work. Middle Pleistocene individuals, materiality and the lifespace at Makapansgat, South Africa. In: Gamble C, Porr M (eds) The hominid individual in context. Archaeological investigations of Lower and Middle Palaeolithic landscapes, locales and artefacts. Routledge, London/New York, pp 176-194

Smolla G (1987) Prehistoric flint mining: the history of research: a review. In: Newcomer MH, de G Sieveking G (eds) The human uses of flint and chert. Cambridge University Press, Cambridge, pp 127-129

Stekelis M, Bar-Yosef O, Schick T (1969) Archaeological excavations at Ubeidiya, 1964-1966. Israel Academy of Sciences and Humanities, Jerusalem

Stevenson MG (1991) Beyond the formation of hearth-associated artifact assemblages. In: Kroll EM, Price TD (eds) The interpretation of archaeological spatial patterning. Plenum Press, New York/London, pp 269-299

Stiles DN (1998) Raw material as evidence for human behaviour in the lower palaeolithic Pleistocene: the Olduvai case. In: Petraglia MD, Korisettar R (eds) Early human behaviour in global context. The rise and discovery of the Lower Palaeolithic record. One world archaeology. Unwin Hyman, Boston/Sydney/Washington, pp 133-150

Stiles DN, Hay RL, O’Neil JR (1974) The MNK chert factory site, Olduvai Gorge, Tanzania. World Archaeol 5(3):285-308

Tarantini M (2012) La nascita della Paletnologia in Italia (1860-1877). Quaderni del Dipartimento di Archeologia e Storia delle Arti, Sezione Archeologia - Università di Siena. All'Insegna del Giglio, Firenze 
Thieme H (2005) The Lower Palaeolithic art of hunting. In: Gamble C, Porr M (eds) The hominid individual in context. Archaeological investigations of Lower and Middle Palaeolithic landscapes, locales and artefacts. Routledge, London/New York, pp 115-132

Toro-Moyano I, de Lumley H, Barsky D, Celiberti V, Cauche D, Moncel M-H, Fajardo B, Toro M (2003) Las industria líticas de Barranco León y Fuenta Nueva 3 de Orce. Estudio técnico y typológico. Análisis traceológico. Resultados preliminaires. In: El Pleistocenico Inferior de Barranco León y Fuenta Nueva 3, Orce (Granada). Memoria cientifíca campañas 1999-2002. Archeología monografías, Junta de Andalucía, Consejería de, Cultura, pp 183-206

Toth N, Schick K (2007) Overview of palaeolithic archeology. In: Henke W, Tattersall I (eds) Handbook of paleoanthropology, vol III, Phylogeny of hominids. Springer, Berlin/Heidelberg/ New York, pp 1943-1963

Vekua A, Lordkipanidze D, Bukhsianidze M (2011) Dmanisi - the oldest Eurasian site of fossil hominines. Archaeol Caucasus 4:16-94 (in Russian)

Vermeersch PM, Paulissen E, Van Peer P (1995) Palaeolithic chert mining in Egypt. Archaeol Polona 33:11-30. Warsaw

Vermeersch PM, Paulissen E, Stokes S, Van Peer P, De Bie M, Steenhoudt F, Missotten S (1997) Middle Palaeolithic chert mining in Egypt. In: Ramos-Millán A, Bustillo MA (eds) Siliceous rocks and culture. Monográfica Arte y Arqueología, vol 42. Universidad de Grenada, pp 173-193

von Strobel V (1998) Universitätsprofessor Dr.Dr. Peregrin von Strobel Naturwissenschaftler zwischen Europa und der neuer Welt. In Various Authors (eds) Pellegrino Strobel (1821-1895) Omaggio nel Centenario della morte. Pubblicazione del Museo di Storia Naturale. Università di Parma, vol 9, pp 21-31

Wagner GA, Rieder H, Zöller L, Mick E (eds) (2007) Homo heidelbergensis. Schlüsselfund der Menschheitsgeschichte. Konrad Theiss, Stuttgart

Washburn SL, Lancaster CS (1968) The evolution of hunting. In: Lee RB, De Vore I (eds) Man the hunter. Aldine, New York, pp 293-303

Whalen NM, Fritz GA (2004) The Oldowan in Arabia. Adumatu 9(1):7-18. Riyadh

Whalen NM, Pease DW (1991) Archaeological surveys in southwest Yemen. Paléorient 17(2):127-131

Whalen NM, Zoboroski M, Schubert K (2002) The Lower Palaeolithic in southwestern Oman. Adumatu 5(1):27-34. Riyadh

Whallon R Jr (1973) Spatial analysis of palaeolithic occupation areas. In: Renfrew C (ed) The explanation of culture change. Models in prehistory. Duckworth, London, pp 115-130

Wynn T (1995) Handaxes enigmas. World Archaeol 27(1):10-24 


\section{Index Terms:}

Chipped stone assemblages_4, 7

Chipped stone assemblages bifacial tools_4

Chipped stone assemblages raw material, workshops, and quarries_7

Hunting weapon_14

Paleoethnology_1-4, 9, 14-15

Paleoethnology

Arabian Peninsula_3

Paleoethnology

chipped stone assemblages_4

Paleoethnology

Dmanisi_4

Paleoethnology

factors_15

Paleoethnology

habitation_9

Paleoethnology

hunting weapon_14

Paleoethnology

stone tool technotypological variability_2 